Article

\title{
Life Cycle Assessment of SEWGS Technology Applied to Integrated Steel Plants
}

\author{
Letitia Petrescu ${ }^{1, *}$, Dora-Andreea Chisalita ${ }^{1}$, Calin-Cristian Cormos ${ }^{1}(\mathbb{D}$, \\ Giampaolo Manzolini ${ }^{2}$ (D) Paul Cobden ${ }^{3}$ and H.A.J. van Dijk ${ }^{3}$ \\ 1 Faculty of Chemistry and Chemical Engineering, Babes-Bolyai University, 11 Arany Janos, \\ RO 4000-28 Cluj-Napoca, Romania; dchisalita@chem.ubbcluj.ro (D.-A.C.); cormos@chem.ubbcluj.ro (C.-C.C.) \\ 2 Politecnico di Milano, Dipartimento di Energia, Via Lambruschini 4, 20156 Milano, Italy; \\ giampaolo.manzolini@polimi.it \\ 3 ECN part of TNO, Netherlands Organisation for Applied Scientific Research (TNO), \\ Sustainable Process Technology, Westerduinweg 3, 1755 LE Petten, The Netherlands; \\ paul.cobden@tno.nl (P.C.); eric.vandijk@tno.nl (H.A.J.v.D.) \\ * Correspondence: letitiapetrescu@chem.ubbcluj.ro; Tel.: +40-264-593833
}

Received: 8 March 2019; Accepted: 22 March 2019; Published: 27 March 2019

check for updates

\begin{abstract}
The environmental evaluation of the sorption-enhanced water-gas shift (SEWGS) process to be used for the decarbonization of an integrated steel mill through life cycle assessment (LCA) is the subject of the present paper. This work is carried out within the STEPWISE H2020 project (grant agreement No. 640769). LCA calculations were based on material and energy balances derived from experimental activities, modeling activities, and literature data. Wide system boundaries containing various upstream and downstream processes as well as the main integrated steel mill are drawn for the system under study. The environmental indicators of the SEWGS process are compared to another carbon capture and storage (CCS) technology applied to the iron and steel industry (e.g., gas-liquid absorption using MEA). The reduction of greenhouse gas emissions for SEWGS technology is about $40 \%$. For the other impact indicators, there is an increase in the SEWGS technology (in the range of $7.23 \%$ to $72.77 \%$ ), which is mainly due to the sorbent production and transportation processes. Nevertheless, when compared with the post-combustion capture technology, based on gas-liquid absorption, from an environmental point of view, SEWGS performs significantly better, having impact factor values closer to the no-capture integrated steel mill.
\end{abstract}

Keywords: life cycle assessment; sorption enhanced water gas shift; carbon capture and storage; integrated steel mill

\section{Introduction}

The iron and steel industry has an essential role in the infrastructural and overall economic development of a country. The construction, transportation, and process industries are some important sectors where steel is used [1].

According to the International Energy Agency (IEA), the iron and steel sector is one of the most significant energy-intensive industries among the manufacturing sectors [2]. The iron and steel industry, after the cement industry, is the second most important in a modern society in terms of production volumes, and it is the first in terms of direct $\mathrm{CO}_{2}$ emissions [3]. Reducing and stabilizing $\mathrm{CO}_{2}$ emissions has become one of the main challenges to confront the iron and steel sector [4]. In this context, it is obvious that the steel sector will require both technical and financial breakthroughs in technology in order to ensure its sustainability [5].

The blast furnace $(\mathrm{BF})$ to basic oxygen furnace (BOF) route and the electric arc furnace (EAF) route are the two most important steel production methods. The first option is investigated in the present 
research work, because it is the most widely used production method, accounting for $65-69 \%$ of the market share [6].

The production of steel at an integrated steel plant is quite complex, and it is achieved using several interrelated processes [7]. The primary processes are coke production, sinter production, iron production, raw steel production, ladle metallurgy, continuous casting, hot rolling, and cold rolling. Besides these, there are other additional plants, such as an air separation unit (ASU) and a power plant (PP), which are also integrated into the steel plant. The interrelation of the primary processes and additional processes belonging to a steel mill is shown in a general flow diagram in [7].

The BF-BOF process is more energy intensive than the EAF process, because of the energy needs (e.g., iron ore reduction in the $\mathrm{BF}$, conditioning of the raw materials, iron ore agglomeration and coking processes). It consumes on average up to $20 \mathrm{GJ} /$ ton of steel (with a potential for improvement of $15-20 \%$ [8]), whereas the EAF process consumes on average 4-6 GJ/ton of steel [2]. Thereby, $\mathrm{CO}_{2}$ emissions are also higher for the BF-BOF process than for the EAF process: about 2 ton $\mathrm{CO}_{2} /$ ton of steel versus $0.3-0.5$ ton $\mathrm{CO}_{2} /$ ton of steel $[8,9]$. Carbon capture and storage (CCS) applied to the steel industry can lead to significant reductions in global carbon dioxide emissions [10]. According to $\mathrm{Xu}$, over $70 \%$ of the $\mathrm{CO}_{2}$ emissions from the iron and steel industry are due to the blast furnace [11]. Beside gaseous emissions, there are also liquid and solid emissions coming out from an integrated steel mill. For instance, the solid wastes from iron and steel factories include slag, steel slag, iron-bearing dust, coal ash and tailings, etc. The disposal for those wastes causes environmental problems, e.g., soil pollution, surface water pollution, and underground water pollution [12]. To reduce the various emissions/wastes from the iron and steel industry, it is essential to quantify them. The quantification of the environmental impact can be performed using tools such as life cycle assessment (LCA). LCA can be used for decision making in product and process (re)design by identifying what materials or processes have the lowest environmental impact. LCA can also give answers regarding how these materials and techniques can become friendlier to the environment [13], and how sustainability can be improved [14,15]. Therefore, LCA is a vital and powerful decision support tool in sustainable development [16]. Taking the life cycle into account will help create reliable and predictable frameworks for cost-effective energy and environmental policies [8].

An environmental evaluation and comparison of an integrated steel mill coupled with various $\mathrm{CO}_{2}$ capture technologies is the main aim of the present work. Two capture technologies were evaluated: a conventional amine-based chemical absorption process using monoethanolamine (MEA) and a more innovative one based on sorption-enhanced water-gas shift (SEWGS) technology. The present technology coupled to an integrated steel mill has been evaluated from technological and economical perspectives, but its environmental impacts has not yet been taken into account in other works $[17,18]$. The scientific literature describes some LCA studies of integrated steel mill as gate-to-gate $[19,20]$ or cradle-to-gate [21] using various system boundaries. Considering the integration of steel mills with carbon capture, a cradle-to-gate LCA for an integrated steel mill without and with carbon capture by both conventional gas-liquid chemical absorption using MEA and a more advanced capture technology based on chemical looping was investigated and discussed in a previous work [22]. The comparison between conventional $\mathrm{CO}_{2}$ capture technology coupled with steel production and the more innovative SEWGS technique has not yet been investigated from the ecological point of view. Compared with the previously published work, besides the employment of the SEWGS technology, this study takes into account different power plant configurations from which the $\mathrm{CO}_{2}$ is captured, the only similarities being in the assumption of the steel plant and the upstream processes corresponding to the steel mill and solvent supply chain.

The paper starts with an introduction to the topic and the importance of the present research. A detailed description of the cases considered and an overview of the LCA methodology used for achieving the intended goal is presented in Section 2. Finally, the results, discussions, and conclusions are detailed in Sections 3-5, respectively. 


\section{Materials and Methods}

\subsection{Case Description}

Two $\mathrm{CO}_{2}$ capture technologies have been considered in the present LCA study: MEA gas-liquid absorption and SEWGS technology. The International Energy Agency Greenhouse Gas (IEAGHG) Report was used as a starting point for the case with MEA carbon capture [6]. The process is based on an absorption-desorption cycle in which $\mathrm{CO}_{2}$ is chemically absorbed by the solvent in an absorption column; furthermore, the rich solvent being regenerated with low-pressure steam ( 3 to 6 bar and 130 to $160{ }^{\circ} \mathrm{C}$ ) in a desorption column releasing the absorbed $\mathrm{CO}_{2}$. A schematic representation of the absorption-desorption cycle is presented in Figure 1.

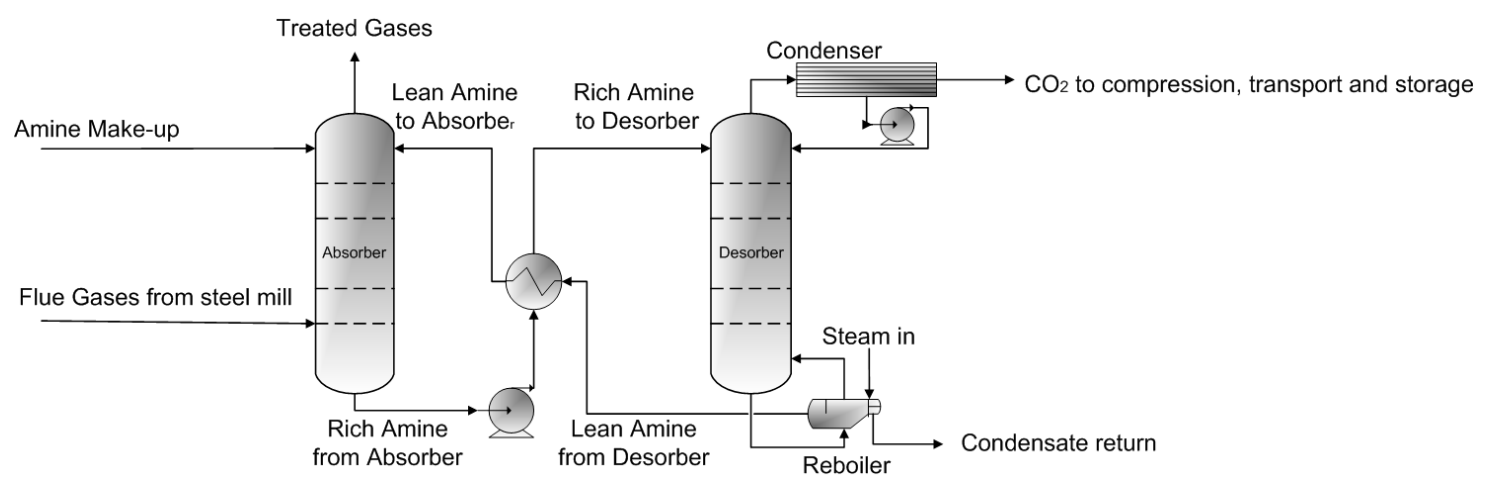

Figure 1. Integrated steel mill using amine-based carbon capture technology.

The coupling of a post-combustion section to the reference integrated steel mill leads to changes of the captive power plant, and the need for a steam generation plant, as the electricity and steam demand will increase due to solvent regeneration. In case of the power plant, the off-gasses burned in the no-capture case for electricity generation are used now to generate steam in a steam generation plant. Hot flue gasses resulting from the gas turbine will be used in a heat recovery steam generation (HRSG) unit [6]. All of the other processes relevant to the production of the hot rolled coils will not suffer any modification compared to the no-capture steel mill.

SEWGS combines the water-gas shift (WGS) reaction with selective adsorption of $\mathrm{CO}_{2}$ on hydrotalcite-based sorbent at high temperature and pressure. The SEWGS unit consists of a system of columns resembling a pressure swing absorption (PSA) allowing the production of continuous streams of products. The process starts by feeding the SEWGS column with a mixture of residual steel gases such as: blast furnace gas (BFG), blast oxygen furnace gas (BOFG), coke oven gas (COG) at high pressure and temperature, followed by $\mathrm{CO}_{2}$ capture and the production of a hydrogen-rich stream in the adsorption step. When the sorbent becomes saturated by $\mathrm{CO}_{2}$ product, the gas feed is redirected to another vessel, while the regeneration of the adsorbent begins in the current vessel. Regeneration starts with a rinse step, where steam displaces $\mathrm{H}_{2}$ and other non-adsorbed gases. This step is significant for $\mathrm{CO}_{2}$ by-product's purity. After the rinse, pressure equalization steps are used to recover both compression energy and the residual $\mathrm{H}_{2}$ that was not flushed out during the rinse step. The $\mathrm{CO}_{2}$ product is recovered in the next two steps: depressurization and purge. Depressurization is carried out counter-currently down to the pressure of $\mathrm{CO}_{2}$ recovery, after which low-pressure steam is used to purge the bed. The purge step significantly influences the carbon capture rate (CCR), as more steam desorbs more $\mathrm{CO}_{2}$ product. Then, the pressure in the column is increased step by step during three pressure equalization steps, and finally, a repressurization step is done by using part of the $\mathrm{H}_{2}$ product $[23,24]$. A schematic representation of an integrated steel mill with SEWGS technology is presented in Figure 2. 


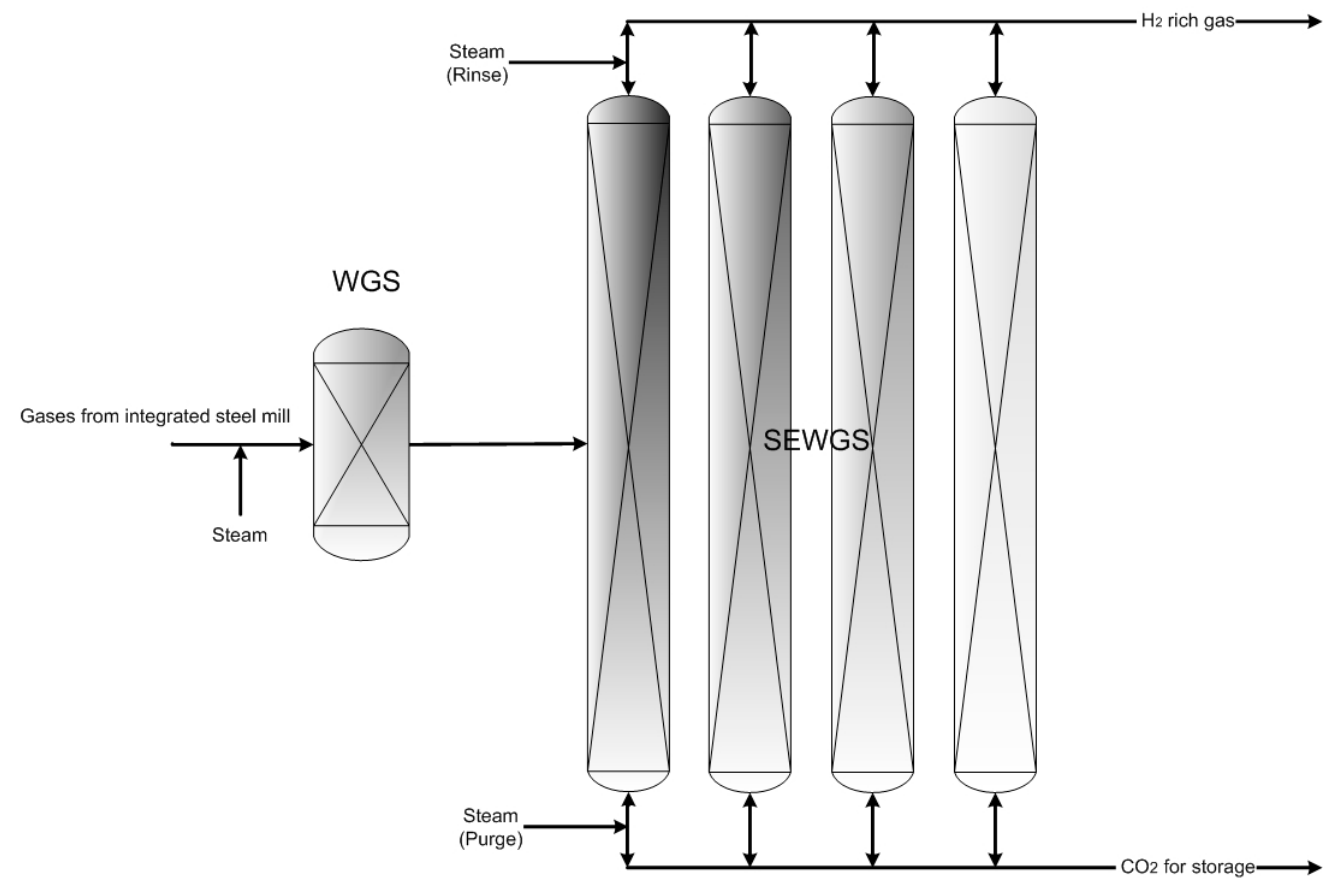

Figure 2. Integrated steel mill with using sorption-enhanced water-gas shift (SEWGS) technology.

Besides the SEWGS unit, the water-gas shift reactor section is also necessary to provide the SEWGS reactor with the right wet gas composition and help reduce the steam consumption for purge and rinse in the SEWGS reactor by performing part of the WGS reaction. Also, the pre-shift unit performing the bulk $\mathrm{CO}_{2}$ conversion is important to reduce the temperature rise inside the SEWGS column.

In an integrated steel mill, $\mathrm{CO}_{2}$ comes from multiple sources, the most significant ones being an onsite power plant and the hot stoves, followed by the sinter and coking plants. The major $\mathrm{CO}_{2}$ sources considered for the present study are illustrated in Figure 3.

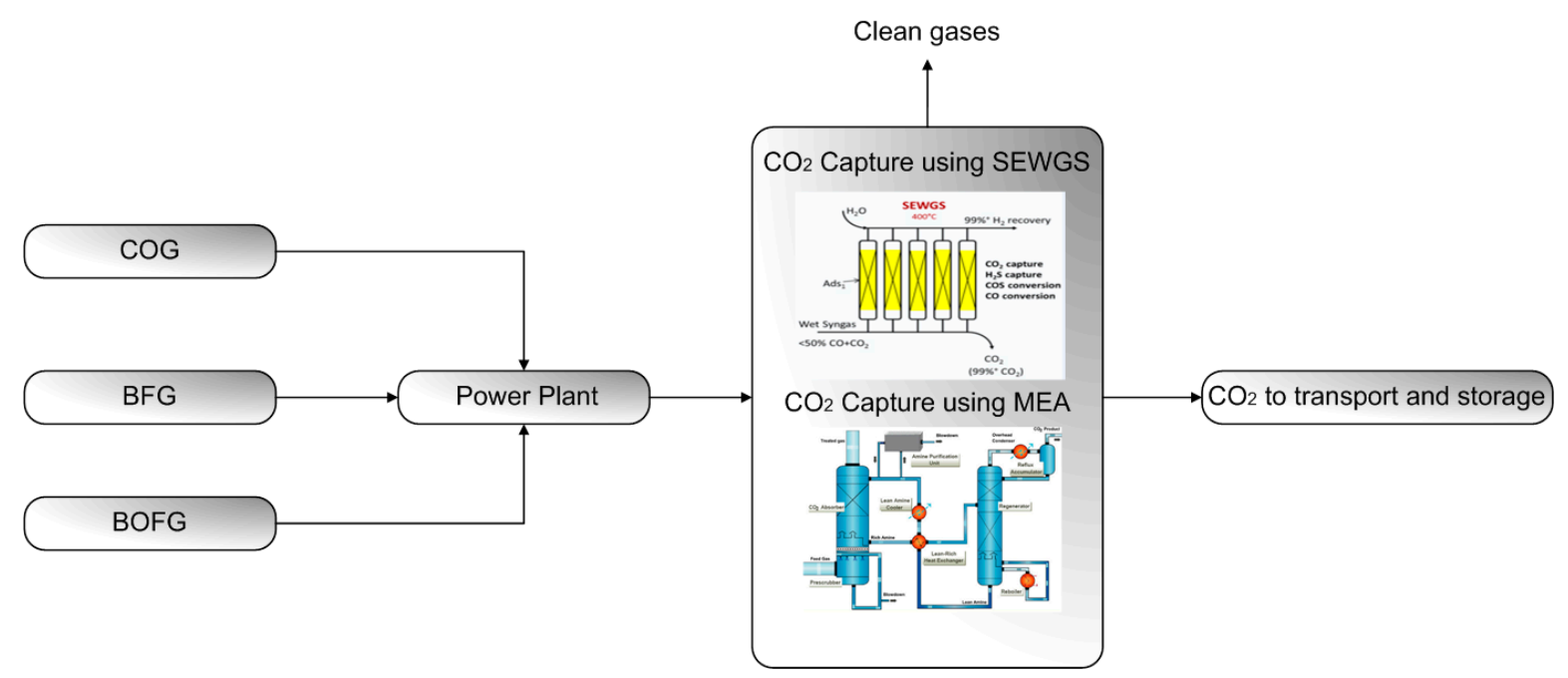

Figure 3. Significant sources of $\mathrm{CO}_{2}$ in the integrated steel mill.

The hot stoves represent the primary emissions point belonging to the hot metal production unit. There are other sources of $\mathrm{CO}_{2}$ in the process mentioned above, such as coal preparation and the blast furnace gas holder, which have been considered in the present study. The steam and power plant units represent other important sources for $\mathrm{CO}_{2}$ capture. The major emission point of $\mathrm{CO}_{2}$ from coke plants is the battery's combustion stack. Lime kilns from the lime production process represent the fourth $\mathrm{CO}_{2}$ source considered in the present study. 
Five case scenarios were proposed for investigation (see Table 1).

Table 1. Cases names and their description.

\begin{tabular}{ll}
\hline \multicolumn{1}{c}{ Case Name } & \multicolumn{1}{c}{ Case Description } \\
\hline Base Case 1 & $\begin{array}{l}\text { Conventional steel plant with a high-efficiency steam turbine power plant and without } \\
\mathrm{CO}_{2} \text { capture }\end{array}$ \\
\hline Base Case 2 & $\begin{array}{l}\text { Conventional steel plant with state-of-the-art gas turbine combined cycle (GTCC) power } \\
\text { plant without } \mathrm{CO}_{2} \text { capture }\end{array}$ \\
\hline Reference Case & $\begin{array}{l}\text { Integrated steel mill with state-of-the-art gas turbine combined cycle (GTCC) with } \\
\text { monoethanolamine-based post-combustion } \mathrm{CO}_{2} \text { capture }\end{array}$ \\
\hline SEWGS EXP & Integrated steel mill using SEWGS technology with an expander for $\mathrm{CO}_{2}$ capture \\
\hline SEWGS SAT & Integrated steel mill using SEWGS technology with saturator for $\mathrm{CO}_{2}$ capture \\
\hline
\end{tabular}

In all of the case scenarios, the basic steelmaking processes do not undergo any changes. The differences between cases consist of the integrated power plant and the carbon capture section. The two base cases (e.g., Base Case 1 and Base Case 2) are described by the integrated steel plant without carbon capture with different power plant specifications. Base Case 1 represents the current industrial situation based on a steam cycle plant. The second option, Base Case 2, characterizes the technology adopted in new steel plants, and it is based on a GTCC (i.e., $2+2+1$ plant configuration with two E-class gas turbines, each with a corresponding HRSG and a steam turbine). The Reference Case is represented by the integrated steel mill with the GTCC power plant (as in Base Case 2) coupled with carbon capture using MEA gas-liquid absorption. These cases serve as a basis for comparison of the integrated steel mill coupled with SEWGS carbon capture technology for which two configurations were investigated: SEGWS EXP, in which the $\mathrm{CO}_{2}$ stream coming from the SEWGS unit is expanded before being cooled and sent to the $\mathrm{CO}_{2}$ compression section, providing additional power to the overall power plant; and SEWGS SAT, in which steam for the WGS unit is partly provided by an upstream saturator recovering low-grade heat by maximizing the steam content of the steel mill off-gases.

\subsection{Life Cycle Assessment ( $L C A)$}

LCA evaluates the environmental impact of a product or service; the assessment is based on a particular function and considers all of the life cycle stages. According to the definitions provided in the International Organization of Standardization (ISO) [25], an LCA consists of four phases, more precisely: (1) goal and scope definition; (2) life cycle inventory analysis; (3) life cycle assessment and; (4) interpretation of the results. Each phase is detailed in the next section.

\subsubsection{Goal and Scope Definition}

The goal of the present study is to quantify and analyze the environmental burden of steelmaking when coupled with different carbon capture technologies, using environmental key performance indicators. Thus, two capture technologies are investigated as potential solutions for decarbonizing the steel industry: a conventional amine-based chemical absorption process using MEA and the innovative $\mathrm{CO}_{2}$ capture technology based on SEWGS. As a more mature and most studied technology, the amine-based adsorption process can provide a suitable baseline reference for comparison with new emerging technologies.

The present study is a "cradle-to-gate" LCA study covering all of the production steps from raw-materials extraction from the earth (i.e., the cradle) to the finished product hot rolled coil (HRC) ready to be shipped from the steelworks (i.e., the gate). Steel is used in many different applications and as a consequence, the use phase has to be modeled by the downstream user of the steel products. This phase was not included in the present LCA study. The boundaries of the study can be extended past the steel mill's gate to include downstream activities such as the degradation of solvents, catalyst, 
and sorbent considered in the capture section. Looking from the carbon life cycle, the study can be considered as a "cradle-to-grave" analysis.

The boundary limits of the present LCA study are drawn around three main processes:

(1) Upstream processes containing raw materials' extraction and transportation to the steel factory, catalyst, solvent, and sorbent manufacturing; (2) The main process, which is represented by the steelmaking process with the corresponding subprocesses (e.g., coke production, sinter production, hot metal production, hot metal desulfurization, primary and secondary steelmaking, continuous casting, reheating and rolling, lime production, air separation unit, and captive power plant); (3) Downstream processes represented by carbon capture units, and the transport and storage of captured $\mathrm{CO}_{2}$.

The system boundaries of the present study are illustrated in Figure 4.

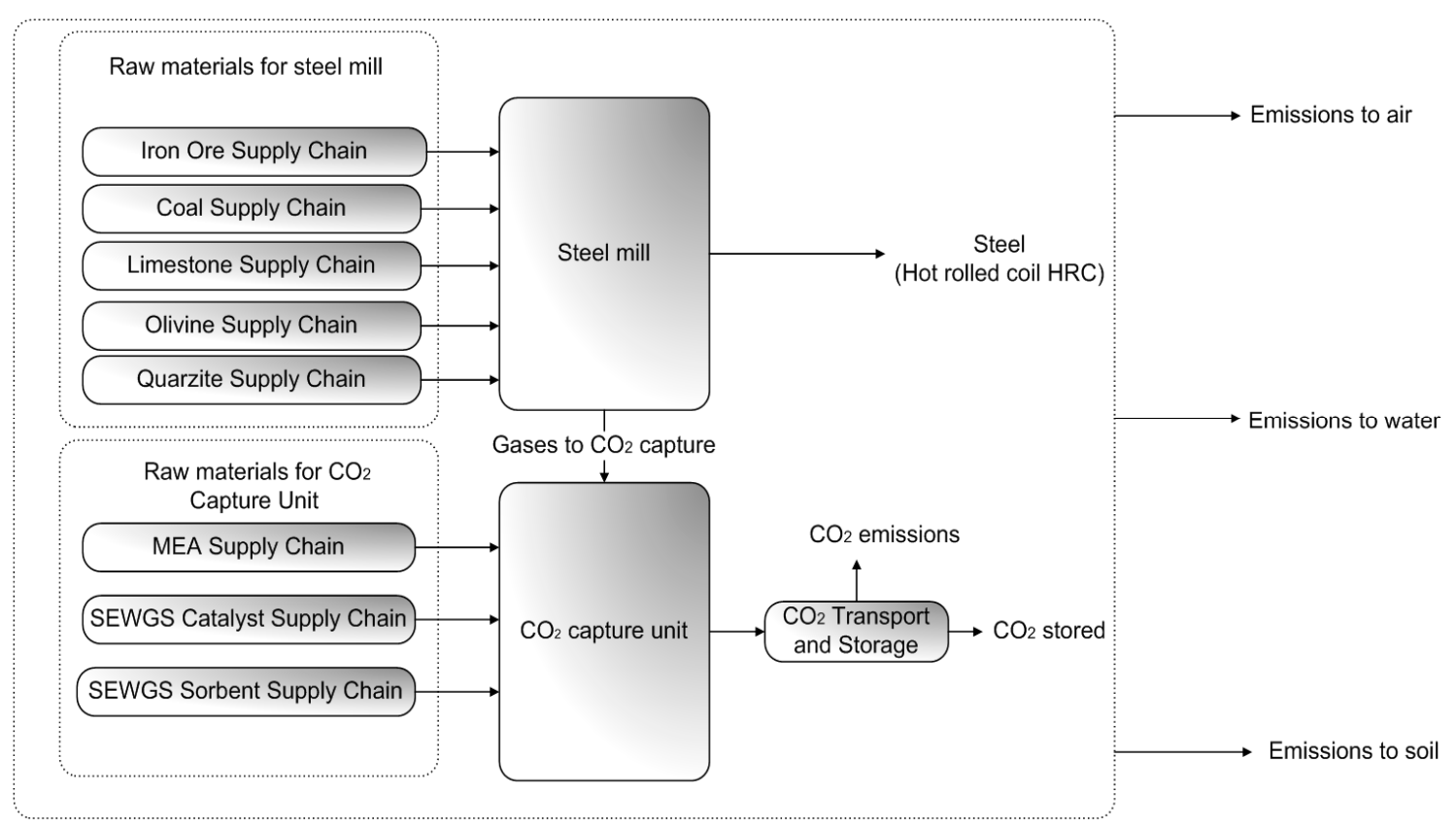

Figure 4. System boundaries for life cycle assessment (LCA) study.

Regarding the geographic and time limits of the investigated system, the current LCA study assumes the plant to be located in The Netherlands (coastal region) having a lifetime of 25 years. The functional unit proposed is one tonne of HRC produced at the factory gate. All of the environmental indicators are reported to this functional unit.

The main assumptions considered for the conventional steel plant are the following: the main process of the LCA study is supposed to be the integrated steel mill with the captive power plant; the conventional steel plant is based on an average Western European steel mill producing 4,000,000 tonnes HRC/year [6]; HRC is the only type of steel product produced and sold; for the steel mill, 8760 operating hours per year are considered; captive ownership of the lime plant and oxygen plant, which means that the $\mathrm{CO}_{2}$ emissions from these facilities are included in the direct emissions of the integrated steel mill; coal for coking and pulverized coal injection (PCI) are the only types of fossil fuel imported; coke production is balanced to meet the steel mill demands; there is no import or export of coke; any excess off-gases that are not used within the steelmaking process are sent to the captive power plant; the steel mill exchanges electricity with the grid as needed; $\mathrm{CO}_{2}$ emissions from the manufacture of purchased pellets, burnt dolomites, and merchant scrap is not accounted for as direct $\mathrm{CO}_{2}$ emissions; granulated $\mathrm{BF}$ slag is not given $\mathrm{CO}_{2}$ emission credit, even if this could be considered as a substitute clinker for the cement industry. Some limitations of the study are presented in the next section. The downstream processing of steel into various products as well as the end of life recycling of steel has not been included in the inventory. Other items not included in the present study are: (1) construction and decommissioning of the integrated steel mill, raw-materials mines, $\mathrm{CO}_{2}$ capture units, and $\mathrm{CO}_{2}$ transport pipelines; (2) repair 
and maintenance of the machinery used in the integrated steel mill and CCS plants; (3) transportation of raw materials for sorbent and catalyst production; (4) construction of infrastructure (e.g., roads, railways) as well as construction of trains and trucks for transportation; (5) installation of railcar unloading facilities; (6) indirect land use; (7) human activities as well as labor costs associated with the number of employees; (8) low-frequency, high-magnitude, non-predictable environmental events (e.g., nonroutine/fugitive/accidental releases); (9) business travel; (10) cleaning and legal services; (11) marketing issues; and (12) operation of administration offices, etc.

\subsubsection{Life Cycle Inventory Analysis}

The life cycle inventory (LCI) data for various subsystems are presented in the next section. The LCI for some raw materials (e.g., coal extraction and transportation, iron ore extraction and transportation, limestone extraction and transportation) are the ones presented in a previous work [22]. Additional data are shown in Tables 2-5.

Table 2. Life cycle inventory (LCI) for hot metal production (all cases).

\begin{tabular}{|c|c|c|c|c|c|c|}
\hline Process & Inputs & All Cases & Units & Outputs & All Cases & Units \\
\hline \multirow{6}{*}{$\begin{array}{l}\text { Raw materials } \\
\text { handling }\end{array}$} & Coke & 366.73 & $\mathrm{~kg} / \mathrm{t}_{\text {HRC }}$ & $\mathrm{BF}$ & 23.45 & $\mathrm{~kg} / \mathrm{t}_{\text {HRC }}$ \\
\hline & Iron ore $65 \%$ & 130.83 & $\mathrm{~kg} / \mathrm{t}_{\text {HRC }}$ & Raw materials to BF & 1965.81 & $\mathrm{~kg} / \mathrm{t}_{\mathrm{HRC}}$ \\
\hline & Limestone & 13.26 & $\mathrm{~kg} / \mathrm{t}_{\mathrm{HRC}}$ & & & \\
\hline & Quartzite & 10.89 & $\mathrm{~kg} / \mathrm{t}_{\text {HRC }}$ & & & \\
\hline & Sinter & 1111.39 & $\mathrm{~kg} / \mathrm{t}_{\mathrm{HRC}}$ & & & \\
\hline & Pellet & 356.17 & $\mathrm{~kg} / \mathrm{t}_{\text {HRC }}$ & & & \\
\hline \multirow{3}{*}{ Coal preparation } & COG & 0.59 & $\mathrm{~kg} / \mathrm{t}_{\mathrm{HRC}}$ & $\begin{array}{l}\text { Metallurgical coal } \\
\text { dried }\end{array}$ & 152.34 & $\mathrm{~kg} / \mathrm{t}_{\mathrm{HRC}}$ \\
\hline & Air & 0.50 & $\mathrm{~kg} / \mathrm{t}_{\text {HRC }}$ & $\mathrm{CO}_{2}$ emissions & 0.98 & $\mathrm{~kg} / \mathrm{t}_{\text {HRC }}$ \\
\hline & Metallurgical coal & 163.93 & $\mathrm{~kg} / \mathrm{t}_{\text {HRC }}$ & Water vapour & 11.61 & $\mathrm{~kg} / \mathrm{t}_{\mathrm{HRC}}$ \\
\hline \multirow{8}{*}{ Blast furnace } & $\begin{array}{l}\text { Metallurgical coal } \\
\text { dried }\end{array}$ & 152.34 & $\mathrm{~kg} / \mathrm{t}_{\mathrm{HRC}}$ & Hot metal & 992.19 & $\mathrm{~kg} / \mathrm{t}_{\mathrm{HRC}}$ \\
\hline & Raw materials to BF & 1965.81 & $\mathrm{~kg} / \mathrm{t}_{\mathrm{HRC}}$ & BFG & 2181.13 & $\mathrm{~kg} / \mathrm{t}_{\mathrm{HRC}}$ \\
\hline & Nitrogen & 963.15 & $\mathrm{~kg} / \mathrm{t}_{\mathrm{HRC}}$ & BF slag & 315.69 & $\mathrm{~kg} / \mathrm{t}_{\mathrm{HRC}}$ \\
\hline & Nitrogen & 6.20 & $\mathrm{~kg} / \mathrm{t}_{\text {HRC }}$ & & & \\
\hline & Oxygen & 359.52 & $\mathrm{~kg} / \mathrm{t}_{\text {HRC }}$ & & & \\
\hline & Water & 0.87 & $\mathrm{~kg} / \mathrm{t}_{\mathrm{HRC}}$ & & & \\
\hline & Compressed air & 43.8 & $\mathrm{Nm}^{3} / \mathrm{t}_{\mathrm{HRC}}$ & & & \\
\hline & Electricity & 370.33 & $\mathrm{MJ} / \mathrm{t}_{\mathrm{HRC}}$ & & & \\
\hline \multirow{7}{*}{ Hot stoves } & $\begin{array}{l}\text { Air from compression } \\
\text { plant }\end{array}$ & 455.18 & $\mathrm{~kg} / \mathrm{t}_{\mathrm{HRC}}$ & $\begin{array}{l}\mathrm{CO}_{2} \text { (to air for the case } \\
\text { without capture; to } \\
\text { CCS for the CCS cases) }\end{array}$ & 414.67 & $\mathrm{~kg} / \mathrm{t}_{\mathrm{HRC}}$ \\
\hline & Air & 1265.19 & $\mathrm{~kg} / \mathrm{t}_{\mathrm{HRC}}$ & Nitrogen & 963.15 & $\mathrm{~kg} / \mathrm{t}_{\mathrm{HRC}}$ \\
\hline & Clean BFG & 639.42 & $\mathrm{~kg} / \mathrm{t}_{\mathrm{HRC}}$ & Nitrogen to air & 633.26 & $\mathrm{~kg} / \mathrm{t}_{\mathrm{HRC}}$ \\
\hline & COG & 3.08 & $\mathrm{~kg} / \mathrm{t}_{\mathrm{HRC}}$ & Oxygen & 359.52 & $\mathrm{~kg} / \mathrm{t}_{\mathrm{HRC}}$ \\
\hline & Oxygen & 67.86 & $\mathrm{~kg} / \mathrm{t}_{\text {HRC }}$ & Oxygen to air & 8.84 & $\mathrm{~kg} / \mathrm{t}_{\mathrm{HRC}}$ \\
\hline & Steam & 7.89 & $\mathrm{~kg} / \mathrm{t}_{\text {HRC }}$ & Water vapor & 39.64 & $\mathrm{~kg} / \mathrm{t}_{\mathrm{HRC}}$ \\
\hline & & & & Water vapor to air & 16.68 & $\mathrm{~kg} / \mathrm{t}_{\mathrm{HRC}}$ \\
\hline \multirow{4}{*}{ BF gas cleaning } & BFG & 2181.13 & $\mathrm{~kg} / \mathrm{t}_{\mathrm{HRC}}$ & $\begin{array}{l}\text { Clean BFG } \\
\text { (to coke plant, power } \\
\text { plant, hot stoves) }\end{array}$ & 2140.67 & $\mathrm{~kg} / \mathrm{t}_{\mathrm{HRC}}$ \\
\hline & Freshwater & 5.19 & $\mathrm{~kg} / \mathrm{t}_{\text {HRC }}$ & BFG to flare & 30.56 & $\mathrm{~kg} / \mathrm{t}_{\mathrm{HRC}}$ \\
\hline & & & & BFG dust & 14.88 & $\mathrm{~kg} / \mathrm{t}_{\mathrm{HRC}}$ \\
\hline & & & & Sludge & 4.41 & $\mathrm{~kg} / \mathrm{t}_{\mathrm{HRC}}$ \\
\hline \multirow{3}{*}{ BF flare } & BFG to flare & 30.56 & $\mathrm{~kg} / \mathrm{t}_{\text {HRC }}$ & $\mathrm{CO}_{2}$ emissions & 19.72 & $\mathrm{~kg} / \mathrm{t}_{\mathrm{HRC}}$ \\
\hline & Air & 19.95 & & $\mathrm{~N}_{2}$ emissions & 29.54 & $\mathrm{~kg} / \mathrm{t}_{\mathrm{HRC}}$ \\
\hline & & & & Water emissions & 1.23 & $\mathrm{~kg} / \mathrm{t}_{\text {HRC }}$ \\
\hline
\end{tabular}

BF: blast furnace; COG: coke oven gas; BFG: blast furnace gas; CCS: carbon capture and storage. 
Table 3. Life cycle inventory (LCI) for primary steelmaking (all cases).

\begin{tabular}{|c|c|c|c|c|c|c|}
\hline Process & Inputs & All Cases & Units & Outputs & All Cases & Units \\
\hline \multirow{10}{*}{ BOF unit } & Iron ore & 5.50 & $\mathrm{~kg} / \mathrm{t}_{\mathrm{HRC}}$ & BOF gas & 142.97 & $\mathrm{~kg} / \mathrm{t}_{\mathrm{HRC}}$ \\
\hline & Argon & 0.84 & $\mathrm{~kg} / \mathrm{t}_{\mathrm{HRC}}$ & BOF slag & 123.46 & $\mathrm{~kg} / \mathrm{t}_{\mathrm{HRC}}$ \\
\hline & Hot metal & 973.56 & $\mathrm{~kg} / \mathrm{t}_{\mathrm{HRC}}$ & Crude steel & 1080.83 & $\mathrm{~kg} / \mathrm{t}_{\mathrm{HRC}}$ \\
\hline & Dolomite & 11.91 & $\mathrm{~kg} / \mathrm{t}_{\mathrm{HRC}}$ & & & \\
\hline & Lime & 70.06 & $\mathrm{~kg} / \mathrm{t}_{\mathrm{HRC}}$ & & & \\
\hline & Nitrogen & 0.41 & $\mathrm{~kg} / \mathrm{t}_{\mathrm{HRC}}$ & & & \\
\hline & Oxygen & 79.63 & $\mathrm{~kg} / \mathrm{t}_{\mathrm{HRC}}$ & & & \\
\hline & Internal scarp & 78.98 & $\mathrm{~kg} / \mathrm{t}_{\mathrm{HRC}}$ & & & \\
\hline & $\begin{array}{l}\text { Steel scrap } \\
\text { (purchased) }\end{array}$ & 126.37 & $\mathrm{~kg} / \mathrm{t}_{\mathrm{HRC}}$ & & & \\
\hline & Electricity & 77.82 & $\mathrm{MJ} / \mathrm{t}_{\mathrm{HRC}}$ & & & \\
\hline \multirow[t]{4}{*}{ BOF gas recovery unit } & BOF gas & 142.97 & $\mathrm{~kg} / \mathrm{t}_{\mathrm{HRC}}$ & BOF gas & 142.97 & $\mathrm{~kg} / \mathrm{t}_{\mathrm{HRC}}$ \\
\hline & Boiler feed water & 76.32 & $\mathrm{~kg} / \mathrm{t}_{\mathrm{HRC}}$ & $\begin{array}{l}\text { Steam to coke } \\
\text { production }\end{array}$ & 61.14 & $\mathrm{~kg} / \mathrm{t}_{\mathrm{HRC}}$ \\
\hline & & & & Steam to iron making & 7.89 & $\mathrm{~kg} / \mathrm{t}_{\mathrm{HRC}}$ \\
\hline & & & & Steam to ASU & 7.28 & $\mathrm{~kg} / \mathrm{t}_{\mathrm{HRC}}$ \\
\hline \multirow{3}{*}{ BOF cleaning unit } & BOF gas & 142.97 & $\mathrm{~kg} / \mathrm{t}_{\mathrm{HRC}}$ & BOF gas & 157.49 & $\mathrm{~kg} / \mathrm{t}_{\mathrm{HRC}}$ \\
\hline & Electricity & 77.82 & $\mathrm{MJ} / \mathrm{t}_{\mathrm{HRC}}$ & BOF sludge & 42.29 & $\mathrm{~kg} / \mathrm{t}_{\mathrm{HRC}}$ \\
\hline & Water & 56.82 & $\mathrm{~kg} / \mathrm{t}_{\mathrm{HRC}}$ & & & \\
\hline \multirow{2}{*}{ Gas holder unit } & BOF gas & 157.49 & $\mathrm{~kg} / \mathrm{t}_{\mathrm{HRC}}$ & BOF to power plant & 112.04 & $\mathrm{~kg} / \mathrm{t}_{\mathrm{HRC}}$ \\
\hline & & & & BOF waste to flare & 45.45 & $\mathrm{~kg} / \mathrm{t}_{\mathrm{HRC}}$ \\
\hline \multirow{3}{*}{ BOF to flare } & BOF waste to flare & 45.45 & $\mathrm{~kg} / \mathrm{t}_{\mathrm{HRC}}$ & $\mathrm{CO}_{2}$ emissions & 50.25 & $\mathrm{~kg} / \mathrm{t}_{\mathrm{HRC}}$ \\
\hline & Air & 72.62 & $\mathrm{~kg} / \mathrm{t}_{\mathrm{HRC}}$ & Nitrogen emissions & 63.57 & $\mathrm{~kg} / \mathrm{t}_{\mathrm{HRC}}$ \\
\hline & & & & Water vapor & 4.27 & $\mathrm{~kg} / \mathrm{t}_{\mathrm{HRC}}$ \\
\hline \multirow{3}{*}{ Slag processing unit } & Slag & 123.46 & $\mathrm{~kg} / \mathrm{t}_{\mathrm{HRC}}$ & Slag waste on landfill & 32.10 & $\mathrm{~kg} / \mathrm{t}_{\mathrm{HRC}}$ \\
\hline & & & & Slag to sinter & 34.57 & $\mathrm{~kg} / \mathrm{t}_{\mathrm{HRC}}$ \\
\hline & & & & Sag to sale & 56.79 & $\mathrm{~kg} / \mathrm{t}_{\mathrm{HRC}}$ \\
\hline
\end{tabular}

BOF: blast oxygen furnace; ASU: air separation unit.

Table 4. LCI data for the captive power plant (PP).

\begin{tabular}{|c|c|c|c|c|c|c|c|}
\hline \multirow[b]{2}{*}{ Inputs } & & \multirow[b]{2}{*}{ Units } & \multicolumn{5}{|c|}{ Evaluated Cases } \\
\hline & & & Base Case 1 & Base Case 2 & $\begin{array}{l}\text { Reference } \\
\text { Case }^{\mathrm{a}}\end{array}$ & $\begin{array}{l}\text { SEWGS } \\
\text { EXP }^{b}\end{array}$ & $\begin{array}{l}\text { SEWGS } \\
\text { SAT }^{b}\end{array}$ \\
\hline Electricity & & $\mathrm{MJ} / \mathrm{t}_{\mathrm{HRC}}$ & 59.92 & 235.73 & 400.11 & 867.47 & 754.50 \\
\hline Air & & $\mathrm{kg} / \mathrm{t}_{\mathrm{HRC}}$ & 1285.09 & 2070.69 & 2238.58 & 2445.24 & 2243.23 \\
\hline Steam to PP & & $\mathrm{kg} / \mathrm{t}_{\text {HRC }}$ & 4.73 & 4.73 & 4.73 & & \\
\hline \multirow{8}{*}{ COG } & $\mathrm{CO}_{2}$ & $\mathrm{~kg} / \mathrm{t}_{\text {HRC }}$ & 0.09 & 0.09 & 0.09 & 0.09 & 0.09 \\
\hline & $\mathrm{CO}$ & $\mathrm{kg} / \mathrm{t}_{\text {HRC }}$ & 0.23 & 0.23 & 0.23 & 0.23 & 0.23 \\
\hline & $\mathrm{C}_{2} \mathrm{H}_{6}$ & $\mathrm{~kg} / \mathrm{t}_{\mathrm{HRC}}$ & 0.17 & 0.17 & 0.17 & 0.17 & 0.17 \\
\hline & $\mathrm{H}_{2}$ & $\mathrm{~kg} / \mathrm{t}_{\text {HRC }}$ & 0.26 & 0.26 & 0.26 & 0.26 & 0.26 \\
\hline & $\mathrm{CH}_{4}$ & $\mathrm{~kg} / \mathrm{t}_{\mathrm{HRC}}$ & 0.79 & 0.79 & 0.79 & 0.79 & 0.79 \\
\hline & $\mathrm{N}_{2}$ & $\mathrm{~kg} / \mathrm{t}_{\mathrm{HRC}}$ & 0.35 & 0.35 & 0.35 & 0.35 & 0.35 \\
\hline & $\mathrm{O}_{2}$ & $\mathrm{~kg} / \mathrm{t}_{\text {HRC }}$ & 0.01 & 0.01 & 0.01 & 0.01 & 0.01 \\
\hline & $\mathrm{H}_{2} \mathrm{O}$ & $\mathrm{kg} / \mathrm{t}_{\text {HRC }}$ & 0.15 & 0.15 & 0.15 & 0.15 & 0.15 \\
\hline \multirow{5}{*}{ BFG } & $\mathrm{CO}_{2}$ & $\mathrm{~kg} / \mathrm{t}_{\text {HRC }}$ & 401.77 & 401.77 & 401.77 & 401.77 & 401.77 \\
\hline & $\mathrm{CO}$ & $\mathrm{kg} / \mathrm{t}_{\mathrm{HRC}}$ & 258.48 & 258.48 & 258.48 & 258.48 & 258.48 \\
\hline & $\mathrm{H}_{2}$ & $\mathrm{~kg} / \mathrm{t}_{\text {HRC }}$ & 3.02 & 3.02 & 3.02 & 3.02 & 3.02 \\
\hline & $\mathrm{N}_{2}$ & $\mathrm{~kg} / \mathrm{t}_{\mathrm{HRC}}$ & 564.40 & 564.40 & 564.40 & 564.40 & 564.40 \\
\hline & $\mathrm{H}_{2} \mathrm{O}$ & $\mathrm{kg} / \mathrm{t}_{\mathrm{HRC}}$ & 23.44 & 23.44 & 23.44 & 23.44 & 23.44 \\
\hline
\end{tabular}


Table 4. Cont.

\begin{tabular}{|c|c|c|c|c|c|c|c|}
\hline \multirow{2}{*}{ Inputs } & & \multirow[b]{2}{*}{ Units } & \multicolumn{5}{|c|}{ Evaluated Cases } \\
\hline & & & Base Case 1 & Base Case 2 & $\begin{array}{l}\text { Reference } \\
\text { Case }^{a}\end{array}$ & $\begin{array}{l}\text { SEWGS } \\
\text { EXP }^{b}\end{array}$ & $\begin{array}{l}\text { SEWGS } \\
\text { SAT }^{\text {b }}\end{array}$ \\
\hline \multirow{5}{*}{ BOFG } & $\mathrm{CO}_{2}$ & $\mathrm{~kg} / \mathrm{t}_{\mathrm{HRC}}$ & 25.02 & 25.02 & 25.02 & 25.02 & 25.02 \\
\hline & $\mathrm{CO}$ & $\mathrm{kg} / \mathrm{t}_{\mathrm{HRC}}$ & 62.77 & 62.77 & 62.77 & 62.77 & 62.77 \\
\hline & $\mathrm{H}_{2}$ & $\mathrm{~kg} / \mathrm{t}_{\mathrm{HRC}}$ & 0.21 & 0.21 & 0.21 & 0.21 & 0.21 \\
\hline & $\mathrm{N}_{2}$ & $\mathrm{~kg} / \mathrm{t}_{\mathrm{HRC}}$ & 15.25 & 15.25 & 15.25 & 15.25 & 15.25 \\
\hline & $\mathrm{H}_{2} \mathrm{O}$ & $\mathrm{kg} / \mathrm{t}_{\text {HRC }}$ & 8.62 & 8.62 & 8.62 & 8.62 & 8.62 \\
\hline \multicolumn{8}{|l|}{ Outputs } \\
\hline Electricity & & $\mathrm{MJ} / \mathrm{t}_{\mathrm{HRC}}$ & 1500.33 & 2074.36 & 1774.22 & 1922.87 & 1822.96 \\
\hline Process Water & & $\mathrm{kg} / \mathrm{t}_{\mathrm{HRC}}$ & 4.38 & 4.38 & - & & \\
\hline \multirow{5}{*}{ Emissions to air } & $\mathrm{Ar}$ & $\mathrm{kg} / \mathrm{t}_{\text {HRC }}$ & 16.38 & 28.55 & 14.23 & 31.19 & 29.40 \\
\hline & $\mathrm{CO}_{2}$ & $\mathrm{~kg} / \mathrm{t}_{\text {HRC }}$ & 936.81 & 937.31 & 468.69 & 73.62 & 69.41 \\
\hline & $\mathrm{N}_{2}$ & $\mathrm{~kg} / \mathrm{t}_{\text {HRC }}$ & 1544.94 & 2260.71 & 1130.43 & 2342.68 & 2208.82 \\
\hline & $\mathrm{O}_{2}$ & $\mathrm{~kg} / \mathrm{t}_{\text {HRC }}$ & 79.92 & 299.24 & 149.58 & 360.31 & 339.72 \\
\hline & $\mathrm{H}_{2} \mathrm{O}$ & $\mathrm{kg} / \mathrm{t}_{\text {HRC }}$ & 71.76 & 50.54 & 25.25 & 255.14 & 240.56 \\
\hline \multirow{5}{*}{$\begin{array}{l}\text { Gas to capture unit }{ }^{\mathrm{a}} / \\
\text { Transport and storage }\end{array}$} & $\mathrm{Ar}$ & $\mathrm{kg} / \mathrm{t}_{\mathrm{HRC}}$ & - & - & 14.23 & & \\
\hline & $\mathrm{CO}_{2}$ & $\mathrm{~kg} / \mathrm{t}_{\mathrm{HRC}}$ & - & - & 468.69 & 833.12 & 833.12 \\
\hline & $\mathrm{N}_{2}$ & $\mathrm{~kg} / \mathrm{t}_{\mathrm{HRC}}$ & - & - & 1130.43 & 18.662 & 18.66 \\
\hline & $\mathrm{O}_{2}$ & $\mathrm{~kg} / \mathrm{t}_{\text {HRC }}$ & - & - & 149.58 & & \\
\hline & $\mathrm{H}_{2} \mathrm{O}$ & $\mathrm{kg} / \mathrm{t}_{\text {HRC }}$ & - & - & 25.25 & & \\
\hline
\end{tabular}

Table 5. LCI for downstream processes: $\mathrm{CO}_{2}$ transport and storage.

\begin{tabular}{lllll}
\hline \multicolumn{2}{c}{ Units } & \multicolumn{3}{c}{ Evaluated Cases } \\
\hline Inputs & & Reference Case & SEWGS EXP & SEWGS SAT \\
\hline $\mathrm{CO}_{2}$ captured & $\mathrm{kg} / \mathrm{t}_{\mathrm{HRC}}$ & 423.14 & 833.12 & 833.12 \\
\hline Electricity for compressors & $\mathrm{kWh} / \mathrm{t}_{\mathrm{HRC}}$ & 0.59 & 1.16 & 1.16 \\
\hline Electricity for injection & $\mathrm{kWh} / \mathrm{t}_{\mathrm{HRC}}$ & 2.96 & 5.83 & 5.83 \\
\hline Outputs & & & & \\
\hline $\mathrm{CO}_{2}$ stored & $\mathrm{kg} / \mathrm{t}_{\mathrm{HRC}}$ & 422.08 & 831.70 & 831.70 \\
\hline $\mathrm{CO}_{2}$ losses pipeline & $\mathrm{kg} / \mathrm{t}_{\mathrm{HRC}}$ & 0.09 & 0.17 & 0.17 \\
\hline $\mathrm{CO}_{2}$ losses compressors & $\mathrm{kg} / \mathrm{t}_{\mathrm{HRC}}$ & 0.21 & 0.42 & 0.42 \\
\hline $\mathrm{CO}_{2}$ losses injection & $\mathrm{kg} / \mathrm{t}_{\mathrm{HRC}}$ & 0.42 & 0.83 & 0.83 \\
\hline
\end{tabular}

\subsubsection{Life Cycle Impact Assessment (LCIA)}

The CML 2001 method assessment, defined by Institute of Environmental Science Leiden University (i.e., Centrum voor Milieuwetenschappen Leiden) and implemented in GaBi v8 software, with the updated database in January 2016, was used for the present LCA study [26,27]. A full environmental assessment is performed, by investigating the following life cycle inventory assessment (LCIA) categories: Global Warming Potential (GWP 100 years); Acidification Potential (AP); Eutrophication Potential (EP); Ozone Depletion Potential (ODP); Aquatic Depletion Potential (ADP); Freshwater Aquatic Ecotoxicity Potential (FAETP); Human Toxicity Potential (HTP); Photochemical Oxidation Potential (PCOP); Terrestrial Ecotoxicity Potential (TEP); and Marine Ecotoxicity Potential (MAETP). 


\section{Results}

The main LCA results are reported in Table 6.

Table 6. LCA results according to CML 2001 (Centrum voor Milieuwetenschappen Leiden).

\begin{tabular}{llccccc}
\hline KPI & Units & Base Case 1 & Base Case 2 & $\begin{array}{c}\text { Reference } \\
\text { Case }\end{array}$ & $\begin{array}{c}\text { SEWGS } \\
\text { EXP }\end{array}$ & $\begin{array}{c}\text { SEWGS } \\
\text { SAT }\end{array}$ \\
\hline $\mathrm{GWP}$ & $\mathrm{kg} \mathrm{CO}_{2}$ equivalents $/ \mathrm{t}_{\mathrm{HRC}}$ & 2093.62 & 2045.90 & 1863.29 & 1252.64 & 1248.44 \\
\hline $\mathrm{AP}$ & $\mathrm{kg} \mathrm{SO}_{2}$ equivalents $/ \mathrm{t}_{\mathrm{HRC}}$ & 0.16 & 0.16 & 11.14 & 0.21 & 0.21 \\
\hline $\mathrm{EP} \times 10^{2}$ & $\mathrm{~kg} \mathrm{PO}_{4}{ }^{3-}$ equivalents $/ \mathrm{t}_{\mathrm{HRC}}$ & 4.13 & 4.13 & 237.00 & 4.85 & 4.85 \\
\hline $\mathrm{ODP} \times 10^{10}$ & $\mathrm{~kg} \mathrm{R11}$ equivalents $/ \mathrm{t}_{\mathrm{HRC}}$ & 14.38 & 14.38 & 15.82 & 14.11 & 14.11 \\
\hline $\mathrm{ADP}_{\text {fossil }}$ & $\mathrm{MJ} / \mathrm{t}_{\mathrm{HRC}}$ & 4580.24 & 4580.24 & 6484.70 & 4911.53 & 4911.53 \\
\hline $\mathrm{FAETP} \times 10^{2}$ & $\mathrm{~kg} \mathrm{1,4} \mathrm{DCB}$ equivalents $/ \mathrm{t}_{\mathrm{HRC}}$ & 29.00 & 29.00 & 73.20 & 32.40 & 32.40 \\
\hline $\mathrm{HTP}$ & $\mathrm{kg} \mathrm{1,4} \mathrm{DCB}$ equivalents $/ \mathrm{t}_{\mathrm{HRC}}$ & 4.43 & 4.43 & 796.60 & 5.52 & 5.52 \\
\hline $\mathrm{PCOP} \times 10^{2}$ & $\mathrm{~kg}$ ethylene equivalents $/ \mathrm{t}_{\mathrm{HRC}}$ & 0.92 & 0.92 & 14.80 & 1.27 & 1.27 \\
\hline $\mathrm{TEP} \times 10^{1}$ & $\mathrm{~kg} 1,4 \mathrm{DCB}$ equivalents $/ \mathrm{t}_{\mathrm{HRC}}$ & 1.29 & 1.29 & 1.6 & 1.44 & 1.44 \\
\hline $\mathrm{MAETP}$ & $\mathrm{kg} 1,4 \mathrm{DCB}$ equivalents $/ \mathrm{t}_{\mathrm{HRC}}$ & 4849.33 & 4849.33 & 10981.91 & 8378.42 & 8378.42 \\
\hline
\end{tabular}

GWP 100 years: Global Warming Potential; AP: Acidification Potential; EP: Eutrophication Potential; ODP: Ozone Depletion Potential; ADP: Aquatic Depletion Potential; FAETP: Freshwater Aquatic Ecotoxicity Potential; HTTP: Human Toxicity Potential; PCOP: Photochemical Oxidation Potential; TEP: Terrestrial Ecotoxicity Potential; MAETP: Marine Ecotoxicity Potential; R11: trichlorofluoromethane; 1,4 DCB: 1,4 diclorbenzene.

In order to validate the LCA methodology, a detailed comparison of the GWP value of each subprocess corresponding to the integrated steel mill and the GWP values found in the scientific literature [6] is displayed in Table 7, showing good agreement between the literature data and those obtained using GaBi software, the relative error being below $2.5 \%$.

Table 7. Methodology results validation.

\begin{tabular}{|c|c|c|}
\hline Source of $\mathrm{CO}_{2}$ Emissions & $\begin{array}{l}\text { Literature Emissions } \\
\left(\mathbf{k g ~ C O} \text { eq. } \text { / } \mathrm{HRC}^{\text {[6] }}\right.\end{array}$ & $\begin{array}{c}\text { LCA Results } \\
\left(\mathrm{kg} \mathrm{CO} \text { eq./t }_{\mathrm{HRC}}\right)\end{array}$ \\
\hline Coke oven (flue gases and flare) & 194.67 & 194.25 \\
\hline Sinter plant (flue gases) & 289.46 & 292.52 \\
\hline Hot stoves (flue gases) & 415.19 & 414.64 \\
\hline Hot metal desulfurization and ancillaries & 7.76 & 5.36 \\
\hline Blast furnace (flare) & 19.73 & 19.72 \\
\hline Blast oxygen furnace (BOF) & 51.02 & 52.35 \\
\hline Continuous casting (diffuse emissions) & 0.80 & 0.80 \\
\hline Reheating furnaces (flue gases) & 57.71 & 57.69 \\
\hline Hot rolling mills (diffuse emissions) & 0.04 & 0.04 \\
\hline Lime plant (flue gases) & 71.62 & 71.53 \\
\hline Power plant (flue gases) & 982.13 & 981.06 \\
\hline TOTAL EMISSIONS & 2090.13 & 2089.96 \\
\hline
\end{tabular}

\section{Discussion}

The highest GWP corresponds to Base Case 1, which represents the conventional steel plant with a high-efficiency steam turbine power plant followed by Base Case 2, which represents the conventional steel plant with the state-of-the-art gas turbine combined cycle (GTCC) power plant. The introduction of the amine-based technology for $\mathrm{CO}_{2}$ capture, using MEA as a solvent (denoted as the Reference Case), leads to a reduction in the GWP indicator of about $11 \%$ compared to Base Case 1 
(e.g., $1863.29 \mathrm{~kg} \mathrm{CO} 2$ equivalents $/ \mathrm{t}_{\mathrm{HRC}}$ versus $2093.62 \mathrm{~kg} \mathrm{CO}$ equivalents $/ \mathrm{t}_{\mathrm{HRC}}$ ) and $8.92 \%$ compared to Base Case 2 (e.g., $1863.29 \mathrm{~kg} \mathrm{CO} 2$ equivalents/t $\mathrm{t}_{\mathrm{HRC}}$ versus $2045.90 \mathrm{~kg} \mathrm{CO}_{2}$ equivalents/ $\mathrm{t}_{\mathrm{HRC}}$ ). The GWP comparison between the evaluated cases is presented in Figure 5. As shown in Table 6, SEWGS EXP technology leads to a reduction of greenhouse gas emissions of about $40 \%$ compared to Base Case 1 (e.g., SEWGS EXP versus Base Case 1; 1252.64 kg CO ${ }_{2}$ equivalents $/ t_{\mathrm{HRC}}$ versus $2093.62 \mathrm{~kg}$ $\mathrm{CO}_{2}$ equivalents $/ \mathrm{t}_{\mathrm{HRC}}$ ), about $39 \%$ compared to Base Case 2 (e.g., $1252.64 \mathrm{~kg} \mathrm{CO} 2$ equivalents $/ \mathrm{t}_{\mathrm{HRC}}$ versus $2045.90 \mathrm{~kg} \mathrm{CO}$ equivalents/ $\mathrm{t}_{\mathrm{HRC}}$ ), and about $33 \%$ when SEWGS EXP is compared to the Reference Case (e.g., $1252.64 \mathrm{~kg} \mathrm{CO} 2$ equivalents/t $\mathrm{t}_{\mathrm{HRC}}$ versus $1863.29 \mathrm{~kg} \mathrm{CO}$ equivalents/t $\mathrm{t}_{\mathrm{HRC}}$ ). If the SEWGS SAT case is evaluated in comparison to the other case studies, the situation is as follows: there is a reduction in the GWP indicator by about $41 \%$ compared to Base Case 1, 39\% compared to Base Case 2, and 33\% compared to the Reference Case.

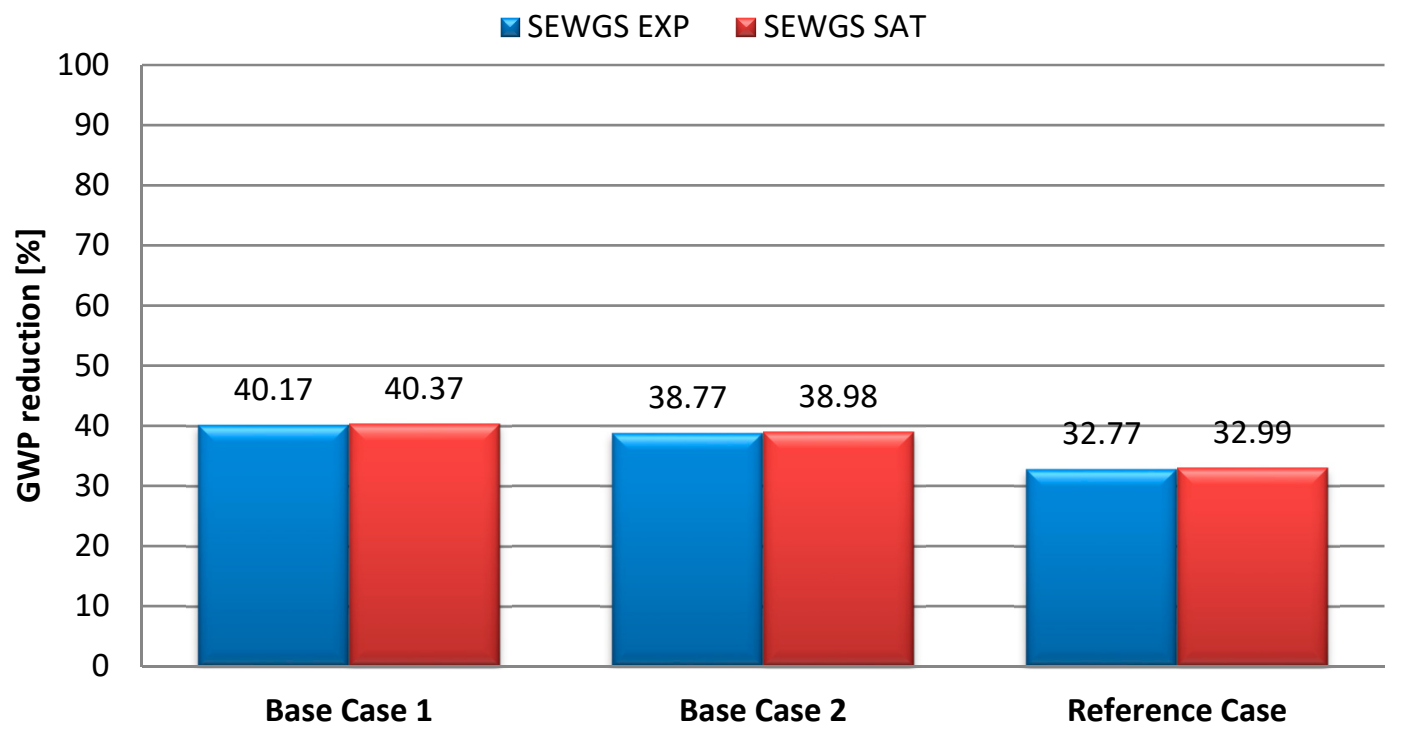

Figure 5. GWP comparison for the evaluated cases.

As shown in Table 6, the lowest values for AP impact category are obtained in Base Case 1 and Base Case 2 (e.g., $16 \times 10^{-2} \mathrm{~kg} \mathrm{SO}_{2}$ equivalents/t $\mathrm{t}_{\mathrm{HRC}}$ ). The introduction of the SEWGS technology for $\mathrm{CO}_{2}$ capture, which is referred to as SEWGS EXP and SEWGS SAT, leads to a slight increase in the AP indicator compared to the base cases; its value is $21 \times 10^{-2} \mathrm{~kg} \mathrm{SO}_{2}$ equivalents $/ \mathrm{t}_{\mathrm{HRC}}$, due to the sorbent production and transportation. The value of AP indicator for the amine-based technology compared to the SEWGS technology is approximately 53 times higher, which is due to the solvent production and degradation processes. Ammonia plays a crucial role in the MEA production, being also an important degradation product. The high quantities of ammonia released during the MEA production and degradation processes are directly connected with the high AP value obtained for the Reference Case.

As in the case of the AP indicator, the EP indicator has also the lowest value for the base cases (e.g., Base Case 1 and Base Case 2). The highest value is obtained in the Reference Case (e.g., $237 \times 10^{-2} \mathrm{~kg} \mathrm{PO}_{4}{ }^{3-}$ equivalents $/ \mathrm{t}_{\mathrm{HRC}}$ ). The processes that bring significant additional impact to the EP indicator are the MEA production and degradation processes, which are processes that are not present in the other cases. If the SEWGS cases, SEWGS EXP and SEWGS SAT, are compared to the base cases, Base Case 1 and Base Case 2, a slight increase in the EP value can be noticed (e.g., $4.85 \times 10^{-2} \mathrm{~kg} \mathrm{PO}_{4}{ }^{3-}$ equivalents/t $\mathrm{t}_{\mathrm{HRC}}$ versus $4.13 \times 10^{-2} \mathrm{~kg} \mathrm{PO}_{4}{ }^{3-}$ equivalents/t $\mathrm{trR}_{\mathrm{HR}}$ ). The increase is due to the sorbent production and transportation processes.

The ODP impact indicator has low and close values for all of the cases under investigation. The highest value (e.g., $15.82 \times 10^{-10} \mathrm{~kg}$ R11 equivalents $/ \mathrm{t}_{\mathrm{HRC}}$ ) is registered for the Reference Case; 
an additional impact to this impact category compared to the other cases is brought by the MEA production and transportation process.

The highest value for Abiotic Depletion Potential Fossil ( $\left.\mathrm{ADP}_{\text {fossil }}\right)$ is obtained in the Reference Case (e.g., $6484.70 \mathrm{MJ} / \mathrm{t}_{\mathrm{HRC}}$ ). The value is about 1.42 times higher compared to the benchmark cases (e.g., $6484.70 \mathrm{MJ} / \mathrm{t}_{\mathrm{HRC}}$ versus $4580.24 \mathrm{MJ} / \mathrm{t}_{\mathrm{HRC}}$ ), and about 1.3 times higher compared to the SEWGS cases (e.g., $6484.70 \mathrm{MJ} / \mathrm{t}_{\mathrm{HRC}}$ versus $4911.53 \mathrm{MJ} / \mathrm{t}_{\mathrm{HRC}}$ ). When $\mathrm{CO}_{2}$ is captured using MEA (see the Reference Case), an additional contribution to the $\mathrm{ADP}_{\text {fossil }}$ impact indicator, compared to the base cases or to the SEWGS cases, is brought by the MEA production, and more specifically by the ethylene oxide and ammonia used for MEA production. The electricity used for MEA production and transportation also has a significant impact on the high value of $\mathrm{ADP}_{\text {fossil }}$.

The major contributors to the FAETP and HTP indicators are the upstream processes, mainly iron ore extraction and transportation, coal extraction and transportation, and limestone extraction and transportation. Only a small share is accountable to the steelmaking process, the main contributors being the primary steelmaking and the power plant. The introduction of CCS technologies leads to higher FAETP and HTP impact indicators, especially for the MEA case (Reference Case), where the degradation products of MEA have elevated toxicity.

Photochemical oxidation potential (PCOP) has the lowest value in the base cases (e.g., $0.92 \times 10^{-2} \mathrm{~kg}$ ethylene equivalents $/ \mathrm{t}_{\mathrm{HRC}}$ ). There is an increase of this indicator in the two cases that use SEWGS technology; the PCOP value becomes $1.27 \times 10^{-2} \mathrm{~kg}$ ethylene equivalents $/ \mathrm{t}_{\mathrm{HRC}}$. The increase is due to the sorbent production and transportation subprocess, and more exactly to the electricity used in the sorbent production supply chain. For the Reference Case, the MEA production and transportation subprocesses lead to a significant increase in the PCOP impact indicator. The increase is about 11 times higher compared to the SEWGS cases. CO, ethylene, and ethylene oxide are the main factors responsible for this high PCOP value in the Reference Case.

Terrestrial ecotoxicity potential (TEP) is another indicator where the CCS cases (Reference Case, SEWGS EXP, and SEWGS SAT) have higher values than the base cases (Base Case 1 and Base Case 2). This is due to the sorbent production and transportation in the SEWGS cases, respectively to the MEA production and transport in the Reference Case.

For the Marine Aquatic Ecotoxicity Potential (MAETP) impact indicator, the lowest value is obtained in the base cases (Base Case 1 and Base Case 2), (e.g., $4849.33 \mathrm{~kg}$ 1,4 DCB equivalents/ $\mathrm{t}_{\mathrm{HRC}}$ ). The major contributors to this impact category are iron extraction and transportation, limestone extraction and transportation, coal extraction and transportation, the primary steelmaking process, and other minor processes. For the SEWGS cases (SEWGS EXP and SEWGS SAT), the MAETP value is $8376.42 \mathrm{~kg} 1,4 \mathrm{DCB}$ equivalents $/ \mathrm{t}_{\mathrm{HRC}}$. An additional impact is brought by sorbent production and transportation, while in the Reference Case, the additional impact is due to the MEA production and transportation processes. The MAETP value reached in the Reference Case is $10981.91 \mathrm{~kg} \mathrm{1,4}$ DCB equivalents $/ t_{H R C}$.

A comparison between the technologies investigated in the STEPWISE project (i.e., SEWGS Technology Platform for cost effective $\mathrm{CO}_{2}$ reduction in the Iron \& Steel Industry) and the post-combustion capture technologies are represented in Figure 6 as the ratio of the impact factors (excluding GWP) of both capture technologies with respect to the impact factor for the no-capture case. Knowing that one represents the same impact factor as the no-capture integrated steel mill, it can be clearly observed that for all of the impact factors, the STEPWISE values are closer to the no-capture steel mill than the reference post-combustion capture case. Thus, it can be concluded that STEPWISE has a much lower overall environmental impact than the post-combustion technologies. 
口Post-combustion MEA-based capture $\square$ SEWEGS EXP

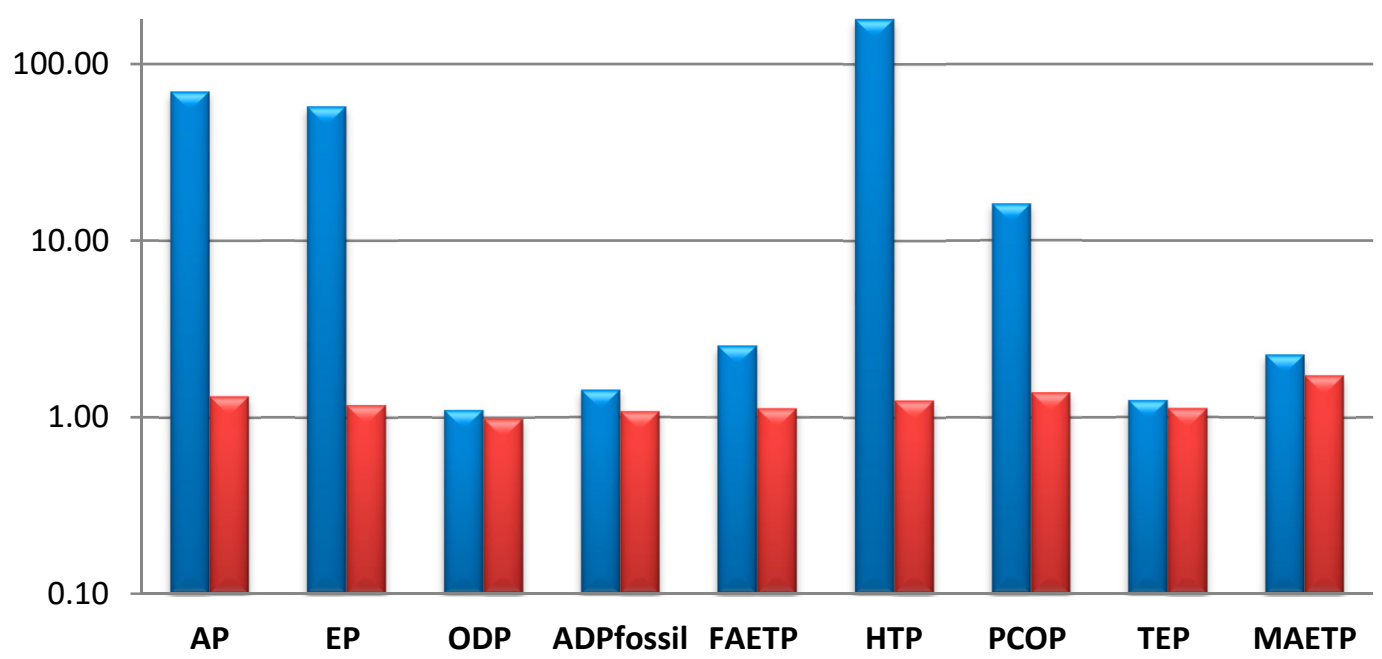

Figure 6. Environmental comparison of STEPWISE vs. post-combustion capture technologies.

The distribution in GWP indicator is presented in Figure 7. After $\mathrm{CO}_{2}$ capture using SEWGS technology, the major contributor to GWP is from the hot metal production subprocess; its contribution is $34.76 \%$ of the total GWP value (e.g., $435.41 \mathrm{~kg} \mathrm{CO}_{2}$ equivalents $/ \mathrm{t}_{\mathrm{HRC}}$ out of the total $1252.64 \mathrm{~kg}$ $\mathrm{CO}_{2}$ equivalents $/ \mathrm{t}_{\mathrm{HRC}}$ ). The sinter production process contributes $22.35 \%$ (e.g., $292.52 \mathrm{~kg} \mathrm{CO}$ equivalents $/ \mathrm{t}_{\mathrm{HRC}}$ from the total $1252.64 \mathrm{~kg} \mathrm{CO} 2$ equivalents $\left./ \mathrm{t}_{\mathrm{HRC}}\right)$. The greenhouse gasses from the coke production process represents $15.53 \%$ from the total GWP value (e.g., $194.25 \mathrm{~kg} \mathrm{CO}$ equivalents $/ \mathrm{t}_{\mathrm{HRC}}$ from the total $1252.64 \mathrm{~kg} \mathrm{CO}$ equivalents/ $\left.\mathrm{t}_{\mathrm{HRC}}\right)$. Other processes with smaller contributions to the GWP indicator are the power plant, lime production and transportation, reheating and rolling mill, and primary steel making. It is also clear that the contributions of the upstream and downstream processes to the total GWP indicator are not so significant. For instance, the $\mathrm{CO}_{2}$ transport and storage contribution to the GWP indicator is minor due to the low quantities of $\mathrm{CO}_{2}$ lost during transportation, compression, and injection.

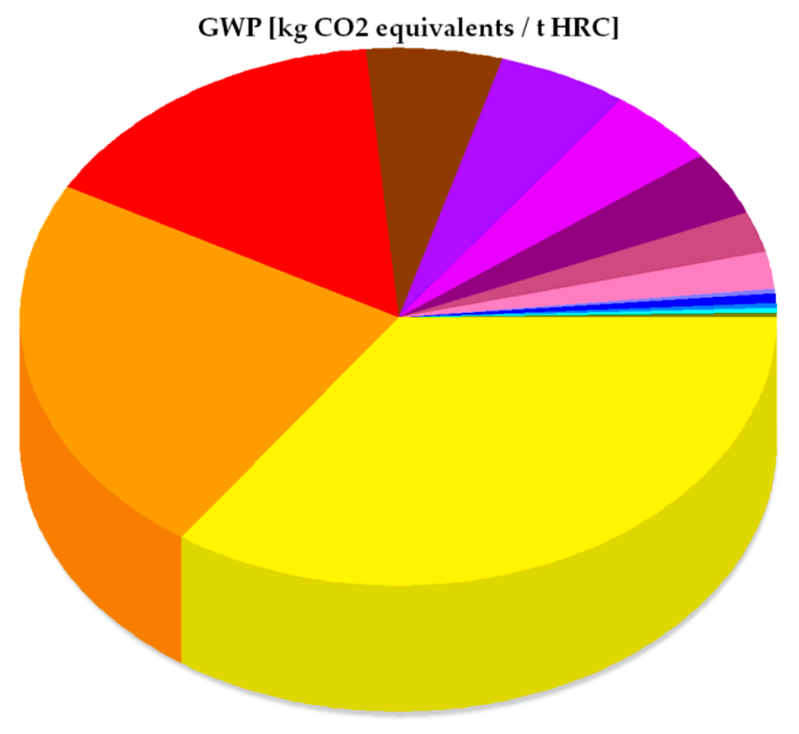

\begin{tabular}{|lr|}
\hline Hot metal production & 435.409 \\
- Sinter production & 292.516 \\
Coke production & 194.252 \\
\hline Power Plant & 73.618 \\
\hline Lime production & 71.532 \\
Reheating \& rolling mills & 57.744 \\
Primary steelmaking & 50.764 \\
- Sorbent production \& transportation & 31.329 \\
Iron ore extraction \& transportation & 25.229 \\
Hot metal desulphurization & 5.360 \\
CO2 transport \& storage & 5.130 \\
Coal extraction \& transportation & 3.993 \\
\hline Limestone extraction \& transportation & 3.915 \\
Secondary steelmaking & 1.576 \\
Continous casting & 0.875 \\
Quartzite extraction \& transportation & 0.527 \\
- Olivine extraction \& transportation & 0.493 \\
- Catalyst production \& transportation & 0.187 \\
ASU & 0 \\
\hline
\end{tabular}

Figure 7. GWP distribution for the SEWGS EXP case.

The distribution of AP indicator for the SEWGS EXP case is reported in Figure 8. Iron ore extraction and transportation, followed by sorbent production and transportation, are the main contributors to this indicator. The iron ore extraction and transportation process represents $57.85 \%$ of 
the total AP indicator (e.g., $11.90 \times 10^{-2} \mathrm{~kg} \mathrm{SO}_{2}$ equivalents $/ \mathrm{t}_{\mathrm{HRC}}$ from the total $21 \times 10^{-2} \mathrm{~kg} \mathrm{SO}_{2}$ equivalents $/ \mathrm{t}_{\mathrm{HRC}}$ ), while the sorbent production and transportation subprocess represents $24.15 \%$ of the total AP indicator (e.g., $4.8 \times 10^{-2} \mathrm{~kg} \mathrm{SO}_{2}$ equivalents $/ \mathrm{t}_{\mathrm{HRC}}$ from the total $21 \times 10^{-2} \mathrm{~kg} \mathrm{SO}_{2}$ equivalents $\left./ t_{\mathrm{HRC}}\right)$.

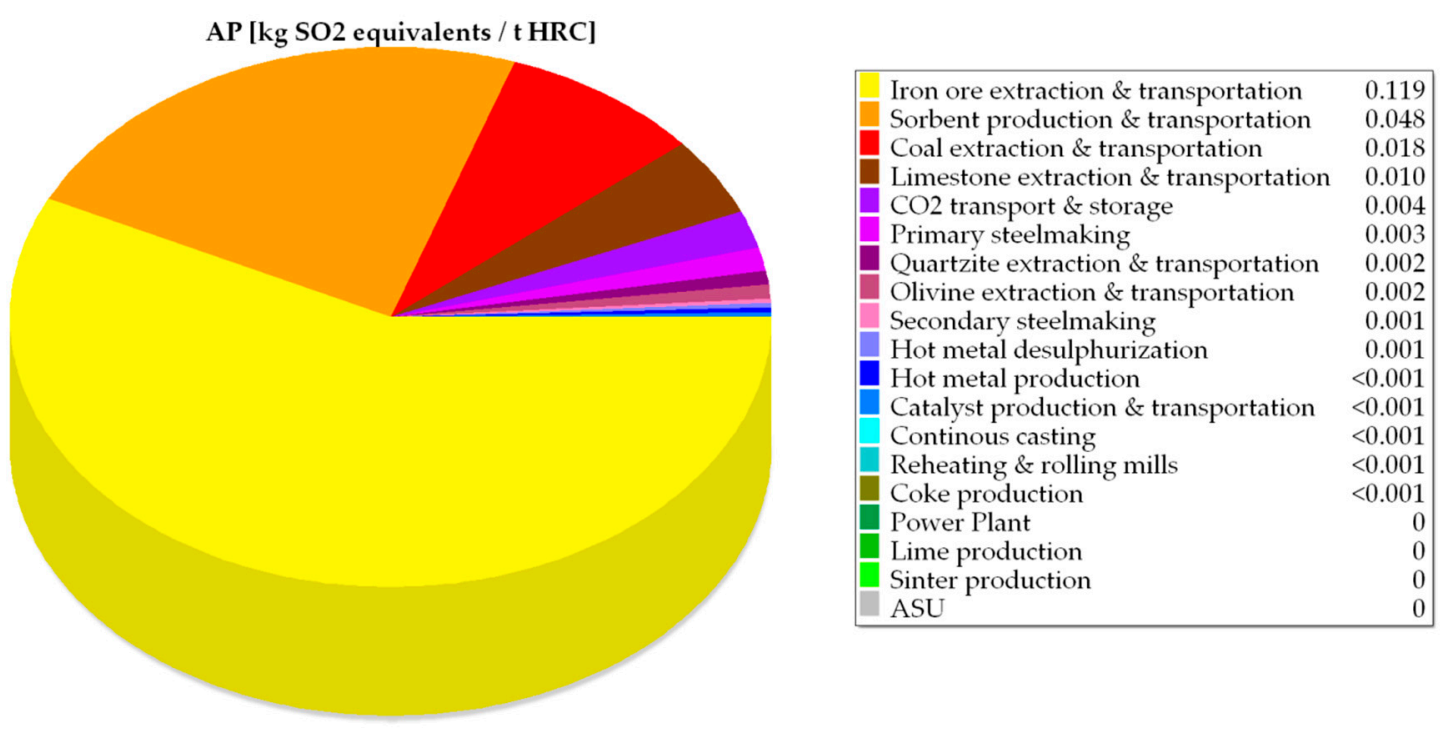

Figure 8. AP distribution for SEWGS EXP case.

The distribution correspondent to the EP indicator is presented in Figure 9, accounting for air emissions. Secondary steelmaking process brings $58 \%$ of the total EP value (e.g., $2.80 \times 10^{-2} \mathrm{~kg} \mathrm{PO}_{4}{ }^{3-}$ equivalents $/ \mathrm{t}_{\mathrm{HRC}}$ from the total of $4.85 \times 10^{-2} \mathrm{~kg} \mathrm{PO}_{4}{ }^{3-}$ equivalents/ $\mathrm{t}_{\mathrm{HRC}}$ ). Iron ore extraction and transportation contribute $18.56 \%$ of the total $\mathrm{EP}$ value. Other processes with minor contribution are sorbent production and transportation, and coal and limestone extraction and transportation.

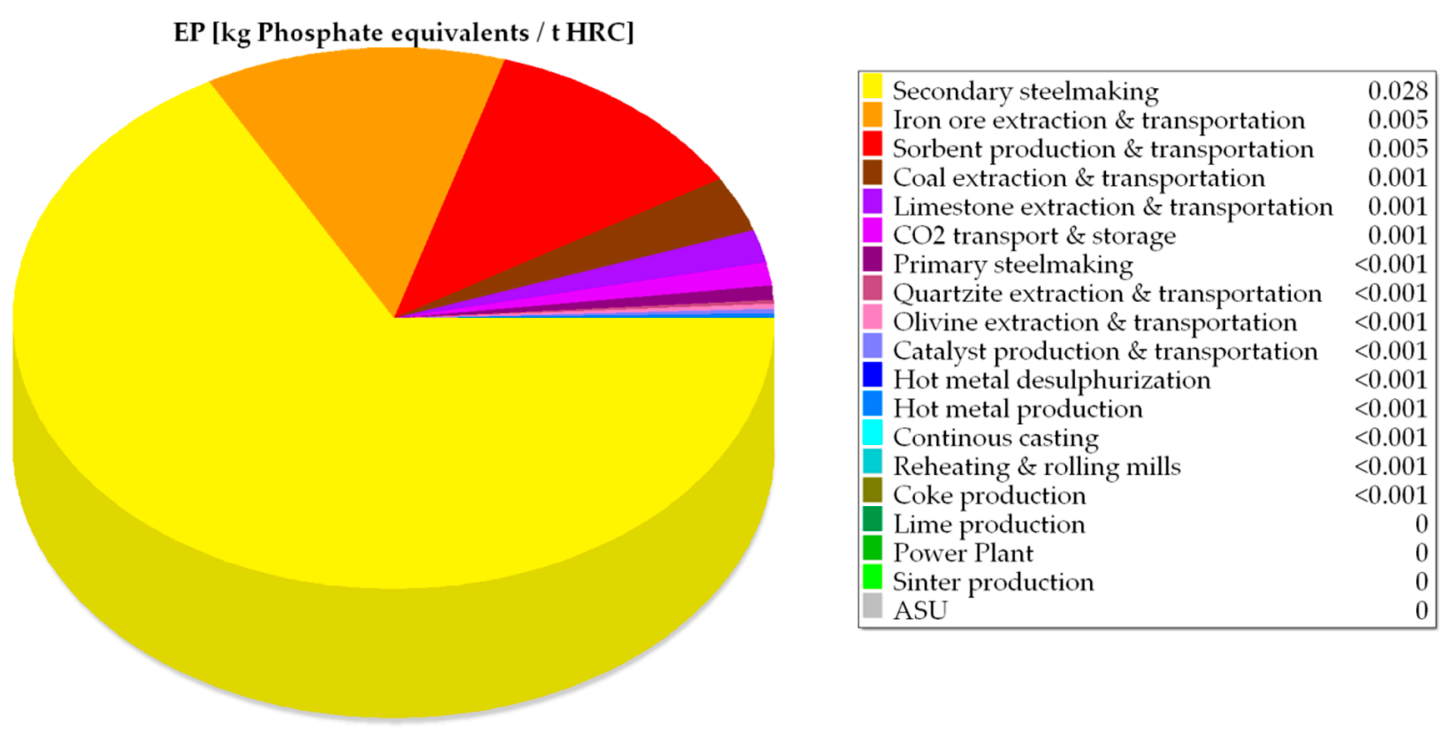

Figure 9. EP distribution for the SEWGS EXP case.

The ODP indicator is predominately influenced by iron ore extraction and transportation (e.g., $12.77 \times 10^{-10} \mathrm{~kg}$ R11 equivalents $/ \mathrm{t}_{\mathrm{HRC}}$ of the total of $14.11 \times 10^{-10} \mathrm{~kg}$ R11 equivalents $/ \mathrm{t}_{\mathrm{HRC}}$ ) respectively by the sorbent production and transportation processes (e.g., $1.21 \times 10^{-10} \mathrm{~kg} \mathrm{R} 11$ equivalents $/ \mathrm{t}_{\mathrm{HRC}}$ of the total of $14.11 \mathrm{~kg}$ R11 equivalents $\left./ \mathrm{t}_{\mathrm{HRC}}\right)$. 
The FAETP impact indicator, which is linked to the lethal dose of the substances involved in the process, is influenced by the following processes: iron ore extraction and transportation, sorbent production and transportation, coal extraction and transportation, and limestone extraction and transportation (see Figure 10). The percentages corresponding to these processes are $94.31 \%$ for the iron ore extraction and transportation subprocess, $2.56 \%$ for the sorbent production and transportation subprocess, $2.11 \%$ for coal extraction and transportation subprocess, and $0.32 \%$ for limestone extraction and transportation subprocess.

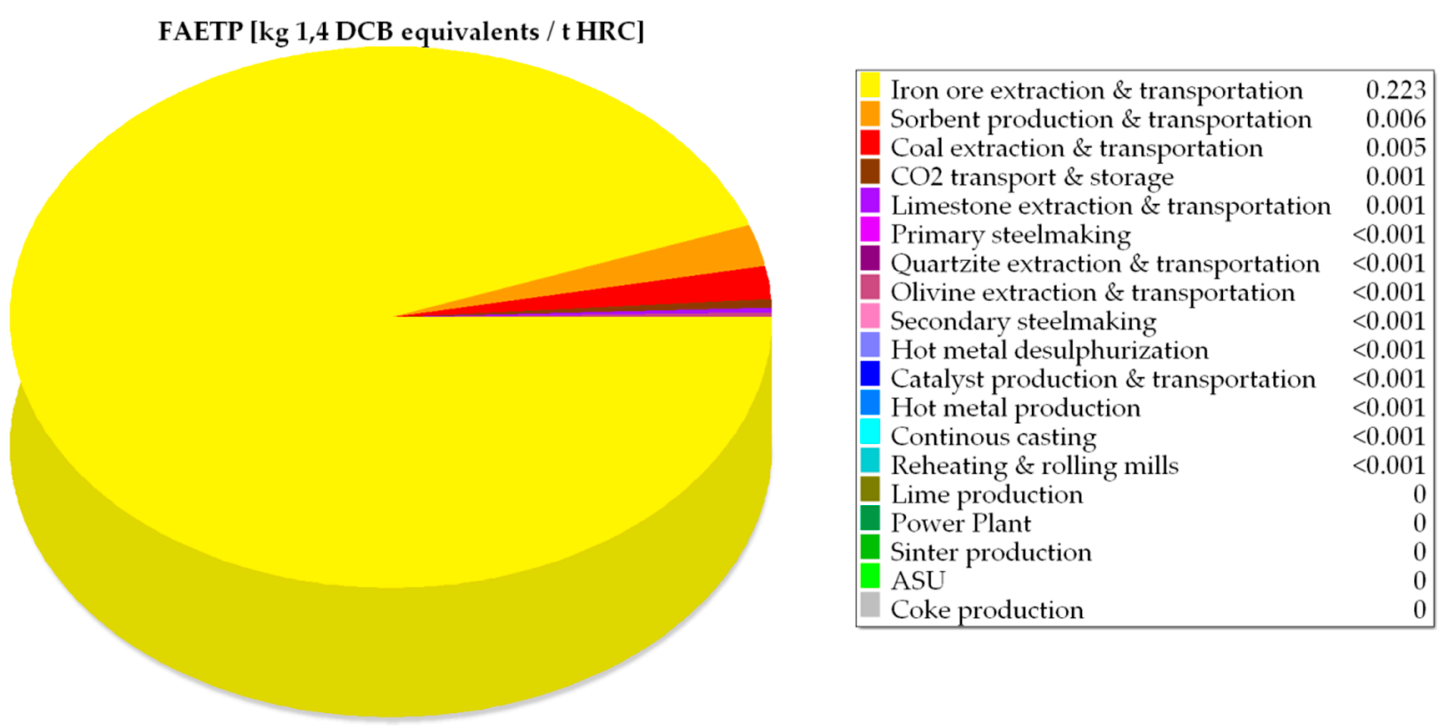

Figure 10. FAETP distribution for the SEWGS EXP case.

The HTP indicator is also related to the lethal dose of the substances involved in the process under study. Similar to the case of the FAETP indicator, iron ore extraction and transportation, followed by the sorbent production and transportation and coal extraction and transportation are the major players in the Human Toxicity Potential indicator.

\section{Conclusions}

The environmental evaluation of an integrated steel mill coupled with CCS technologies is discussed in the present paper. Two $\mathrm{CO}_{2}$ capture technologies have been investigated. The first one is a conventional technology based on amine gas-liquid absorption, using MEA as a solvent, while the second technology is a more innovative one based on SEWGS $\mathrm{CO}_{2}$ capture. The studied capture processes aim to capture the $\mathrm{CO}_{2}$ emissions from the power section of the integrated steel mill. Five scenarios have been considered in the present research project. The five scenarios are:

Base Case 1: Conventional steel plant with a high-efficiency steam turbine power plant and without $\mathrm{CO}_{2}$ capture

Base Case 2: Conventional steel plant with a state-of-the-art GTCC power plant and without $\mathrm{CO}_{2}$ capture

Reference Case: Integrated steel mill with state-of-the-art GTCC with monoethanolamine-based post-combustion $\mathrm{CO}_{2}$ capture

SEWGS EXP: Integrated steel mill using SEWGS technology with expander for $\mathrm{CO}_{2}$ capture

SEWGS SAT: Integrated steel mill using SEWGS technology with saturator for $\mathrm{CO}_{2}$ capture

The environmental impact assessment for the five cases was performed using the LCA methodology, implemented in GaBi software. The environmental assessment is based on three data sources: industrial data, literature data, and process modeling and simulation data. A "cradle-to-grave" approach considering the following system boundaries was considered: (1) upstream processes 
containing the extraction and transportation of raw materials (e.g., iron ore, metallurgical coal, limestone, quartzite, and olivine) used in the steel production process; (2) the main process, which is represented by the steel production process with all of the correspondent subprocesses (e.g., coke production, sinter production, metal production, hot metal desulfurization, primary and secondary steelmaking, continuous casting, reheating and rolling, lime production, air separation unit, and power plant; and (3) downstream processes represented by $\mathrm{CO}_{2}$ capture units as well as $\mathrm{CO}_{2}$ transport and storage for the same cases. The integrated steel mill produces 4 million tons of HRC/year. The functional unit proposed is one tonne of HRC. All of the environmental key performance indicators are reported to the functional unit. Ten environmental impact categories were defined, calculated, and compared among various evaluated integrated steel mills with and without $\mathrm{CO}_{2}$ capture. Discussions about all of the indicators are reported in the present paper. As the results show, the introduction of CCS technologies has significant environmental benefits in term of reducing greenhouse gas (GHG) emissions. For instance, for SEWGS technology, the reduction is about $40 \%$ compared to the base cases, and around 33\% compared to the Reference Case, which is quite significant considering that the maximum capture rate that can be allowed concerning only the power plant is about $45-50 \%$ due to the high $\mathrm{CO}_{2}$ intensity of the iron and steel-making processes. For the other impact indicators, there is an increase of the SEWGS technology, compared to the base cases, which is mainly due to the sorbent production and transportation processes. The improvement in the other environmental impact indicators is in the range of $7.23 \%$ to $72.77 \%$. The highest growth is registered for the MAETP impact indicator, followed by the PCOP impact indicator. A sensitivity analysis was also performed on the sorbent production and transportation subprocess to bring the values of SEWGS technology closer to the base cases values. The production and transportation of MEA for the Reference Case has a significant impact on the AP, EP, and HTP, and MAETP impact indicators. When comparing the two capture technologies by looking at the increase ratio of most of the environmental impact factors with respect to the values obtained for the no-capture integrated steel mill, STEPWISE shows smaller variation from the base case, which leads to the conclusion that SEWGS has a much lower overall environmental impact than amine-based post-combustion capture technologies. The contributions of catalyst production and transportation or downstream processes such as $\mathrm{CO}_{2}$ transport and storage are not significant from an environmental point of view.

Author Contributions: L.P., D.-A.C. and C.-C.C. performed the LCA calculations and prepared the manuscript, G.M. carried out the simulation work on which LCA models are based, H.A.J.v.D. and P.C. performed the expermiental work for SEWGS technology and revised the manuscript. All authors discussed the results and contributed to the final version of the manuscript.

Funding: This research part of STEPWISE project has received funding from the European Union's Horizon 2020 research and innovation programme under grant agreement No. 640769.

Conflicts of Interest: The authors declare no conflict of interest.

\section{Abbreviations}

$\begin{array}{ll}\text { ADP } & \text { Abiotic Depletion Potential } \\ \text { AP } & \text { Acidification Potential } \\ \text { ASU } & \text { Air Separation Unit } \\ \text { BF } & \text { Blast Furnace } \\ \text { BFG } & \text { Blast Furnace Gas } \\ \text { BOF } & \text { Blast Oxygen Furnace } \\ \text { BOFG } & \text { Basic Oxygen Furnace Gas } \\ \text { CCR } & \text { Carbon Capture Rate } \\ \text { CCS } & \text { Carbon Capture and Storage } \\ \text { COG } & \text { Coke Oven Gas } \\ \text { CML } & \text { Institute of Environmental Science Leiden University } \\ & \text { (i.e., Centrum voor Milieuwetenschappen Leiden) }\end{array}$




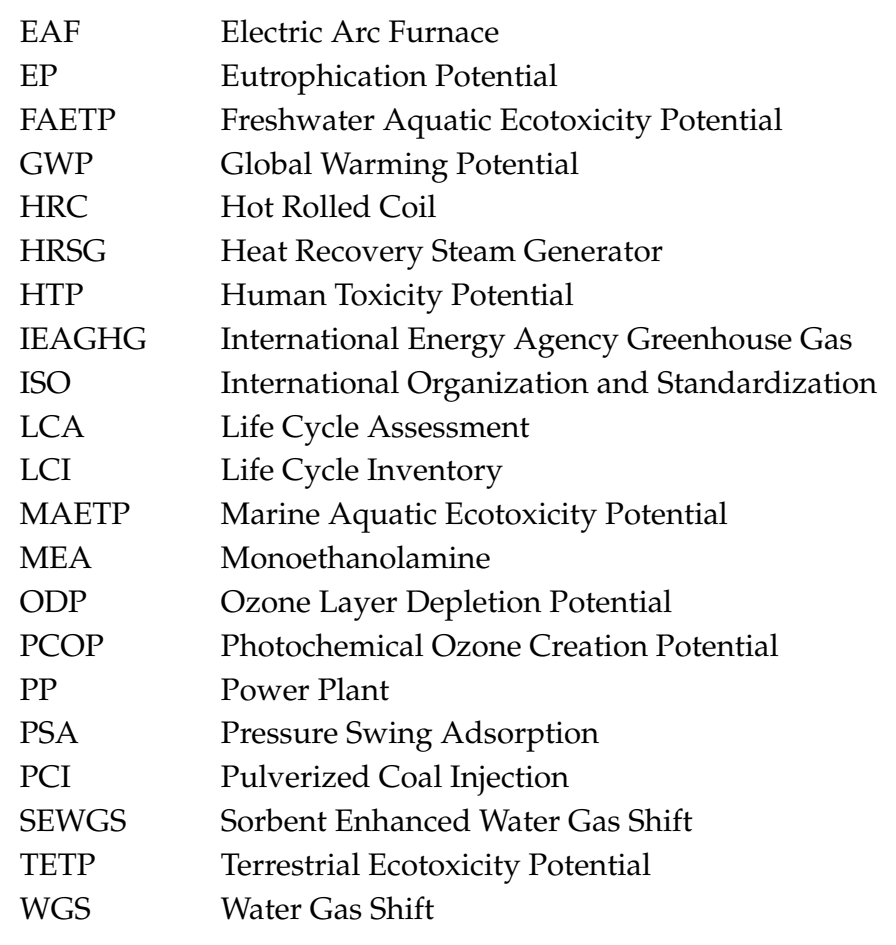

\section{References}

1. Wang, L.K.; Shammas, N.K.; Hung, Y.-T. Waste Treatment in the Metal Manufacturing, Forming, Coating, and Finishing Industries; CRC Press: Boca Raton, FL, USA, 2016; ISBN 1420072242.

2. IEA (International Energy Agency). Energy Technology Perspectives 2010 Scenarios and Strategies to 2050; IEA: Paris, France, 2010.

3. Ramírez-Santos, Á.A.; Castel, C.; Favre, E. A review of gas separation technologies within emission reduction programs in the iron and steel sector: Current application and development perspectives. Sep. Purif. Technol. 2018, 194, 425-442. [CrossRef]

4. Ho, M.T.; Bustamante, A.; Wiley, D.E. Comparison of $\mathrm{CO}_{2}$ capture economics for iron and steel mills. Int. J. Greenh. Gas Control 2013, 19, 145-159. [CrossRef]

5. García, S.G.; Montequín, V.R.; Fernández, R.L.; Fernández, F.O. Evaluation of the synergies in cogeneration with steel waste gases based on Life Cycle Assessment: A combined coke oven and steelmaking gas case study. J. Clean. Prod. 2019, 217, 576-583. [CrossRef]

6. IEAGHG Iron and Steel CCS Study (Techno-Economics Integrated Steel Mill); 2013/04; IEAGHG: Cheltenham, UK, 2013.

7. Huang, Z.; Ding, X.; Sun, H.; Liu, S. Identification of main influencing factors of life cycle $\mathrm{CO}_{2}$ emissions from the integrated steelworks using sensitivity analysis. J. Clean. Prod. 2010, 18, 1052-1058. [CrossRef]

8. WSA (World Steel Association). Steel's Contribution to a Low Carbon Future and Climate Resilient Societies-Worldsteel Position Paper; WSA: Brussels, Belgium, 2017; ISBN 978-2-930069-83-8.

9. IEA (International Energy Agency). Tracking Industrial Energy Efficiency and $\mathrm{CO}_{2}$ Emissions; IEA: Paris, France, 2007.

10. Leeson, D.; Fennell, P.; Shah, N.; Petit, C.; Dowell, N. Mac A Techno-economic Analysis and Systematic Review of Carbon Capture and Storage (CCS) Applied to the Iron and Steel, Cement, Oil Refining and Pulp and Paper Industries. Energy Procedia 2017, 114, 6297-6302. [CrossRef]

11. Xu, K.D. Low carbon economy and iron and steel industry. Iron Steel 2010, 45, 1-12.

12. Bo, C.; Yang, J.; Ouyang, Z. Life cycle assessment of internal recycling options of steel slag in Chinese iron and steel industry. J. Iron Steel Res. Int. 2011, 18, 33-40.

13. Manso, M.; Castro-Gomes, J.; Paulo, B.; Bentes, I.; Teixeira, C.A. Life cycle analysis of a new modular greening system. Sci. Total Environ. 2018, 627, 1146-1153. [CrossRef] [PubMed]

14. Ortiz, O.; Castells, F.; Sonnemann, G. Sustainability in the construction industry: A review of recent developments based on LCA. Constr. Build. Mater. 2009, 23, 28-39. [CrossRef] 
15. Teixeira, C.A.; Russo, M.; Matos, C.; Bentes, I. Evaluation of operational, economic, and environmental performance of mixed and selective collection of municipal solid waste: Porto case study. Waste Manag. Res. 2014, 32, 1210-1218. [CrossRef] [PubMed]

16. Wolf, M.-A.; Chomkhamsri, K.; Brandao, M.; Pant, R.; Ardente, F.; Pennington, D.W.; Manfredi, S.; de Camillis, C.; Goralczyk, M. ILCD Handbook—General Guide for Life Cycle Assessment_Detailed Guidance; European Commission—Joint Research Center-Institute for Environment and Sustainability: Ispra, Italy, 2010.

17. Gazzani, M.; Romano, M.; Manzolini, G. Application of Sorption Enhanced Water Gas Shift for Carbon Capture in Integrated Steelworks. Energy Procedia 2013, 37, 7125-7133. [CrossRef]

18. Gazzani, M.; Romano, M.C.; Manzolini, G. $\mathrm{CO}_{2}$ capture in integrated steelworks by commercial-ready technologies and SEWGS process. Int. J. Greenh. Gas Control 2015, 41, 249-267. [CrossRef]

19. Burchart-Korol, D. Life cycle assessment of steel production in Poland: A case study. J. Clean. Prod. 2013, 54, 235-243. [CrossRef]

20. Olmez, G.M.; Dilek, F.B.; Karanfil, T.; Yetis, U. The environmental impacts of iron and steel industry: A life cycle assessment study. J. Clean. Prod. 2016, 130, 195-201. [CrossRef]

21. World Steel Association. Life Cycle Assessment Methodology Report; World Steel Association: Brussels, Belgium, 2011; ISBN 978-2-930069-66-1.

22. Chisalita, D.-A.; Petrescu, L.; Cobden, P.; van Dijk, H.E.; Cormos, A.-M.; Cormos, C.-C. Assessing the environmental impact of an integrated steel mill with post-combustion $\mathrm{CO}_{2}$ capture and storage using the LCA methodology. J. Clean. Prod. 2019, 211, 1015-1025. [CrossRef]

23. Boon, J.; Cobden, P.D.; van Dijk, H.A.J.; van Sint Annaland, M. High-temperature pressure swing adsorption cycle design for sorption-enhanced water-gas shift. Chem. Eng. Sci. 2015, 122, 219-231. [CrossRef]

24. Gazzani, M.; Macchi, E.; Manzolini, G. $\mathrm{CO}_{2}$ capture in integrated gasification combined cycle with SEWGS-Part A: Thermodynamic performances. Fuel 2013, 105, 206-219. [CrossRef]

25. The International Standards Organization. Environmental Management_Life Cycle Assessment_Principles and Framework; The International Standards Organization: Geneva, Switzerland, 2006; Volume 2006.

26. PE International GaBi thinkstep. Available online: https://www.thinkstep.com/ (accessed on 25 February 2019).

27. Curran, M.A. (Ed.) Life Cycle Assessment Handbook: A Guide for Environmentally Sustainable Products; John Wiley \& Sons: Hoboken, NJ, USA, 2012.

(C) 2019 by the authors. Licensee MDPI, Basel, Switzerland. This article is an open access article distributed under the terms and conditions of the Creative Commons Attribution (CC BY) license (http://creativecommons.org/licenses/by/4.0/). 